Article

\title{
Environmental and Economic Factors of Migration from Urban to Rural Areas: Evidence from Poland
}

\author{
Romuald Jończy ${ }^{1}$, Przemysław Śleszyński ${ }^{2} \mathbb{D}$, Alicja Dolińska ${ }^{1} \mathbb{D}$, Michał Ptak ${ }^{1}$, Justyna Rokitowska-Malcher ${ }^{1} \mathbb{D}$ \\ and Diana Rokita-Poskart ${ }^{3, *}$ (D) \\ 1 Department of Economics and Research on Development, Faculty of Economics and Finance, \\ Wroclaw University of Economics and Business, 53-345 Wroclaw, Poland; romuald.jonczy@ue.wroc.pl (R.J.); \\ alicja.dolinska@ue.wroc.pl (A.D.); michal.ptak@ue.wroc.pl (M.P.); \\ justyna.rokitowska-malcher@ue.wroc.pl (J.R.-M.) \\ 2 Institute of Geography and Spatial Organization of Polish Academy of Sciences, 00-818 Warsaw, Poland; \\ psleszyn@twarda.pan.pl \\ 3 Department of Regional Policy and Labour Market, Faculty of Economics and Management, Opole University \\ of Technology, 45-758 Opole, Poland \\ * Correspondence: d.rokita-poskart@po.edu.pl
}

check for

updates

Citation: Jończy, R.; Śleszyński, P.;

Dolińska, A.; Ptak, M.;

Rokitowska-Malcher, J.;

Rokita-Poskart, D. Environmental and Economic Factors of Migration from Urban to Rural Areas: Evidence from Poland. Energies 2021, 14, 8467. https://doi.org/10.3390/ en14248467

Academic Editor: Peter V. Schaeffer

Received: 2 November 2021

Accepted: 9 December 2021

Published: 15 December 2021

Publisher's Note: MDPI stays neutral with regard to jurisdictional claims in published maps and institutional affiliations.

Copyright: (c) 2021 by the authors. Licensee MDPI, Basel, Switzerland. This article is an open access article distributed under the terms and conditions of the Creative Commons Attribution (CC BY) license (https:/ / creativecommons.org/licenses/by/ $4.0 /)$.
Abstract: The net migration rate is highly diversified and noticeable chiefly in municipalities directly adjacent to large cities. This trend is still maintained in Poland and is now becoming even more visible than previously. Most of the studies conducted to date have not focused on extracting economic and environmental factors or determining the role of individual factors in those decisions. Furthermore, they have not analysed the issue of differences in motives and directions of migration. Thus, the aim of the research was to establish the factors that determine contemporary migrations from the city to suburban areas and to outline the role of economic and environmental factors. For this purpose, 164 interviews were conducted with individuals who had migrated from the city to the countryside surrounding one of the most important urban centres in Central Europe-Wrocław. In the research, the multiple snowball sampling technique was used. It was found that the factors with the most significant impact on the decision to move from the city to the countryside were those of an environmental nature, whereas the selection of a specific location (village) was to a greater extent determined by economic factors. Compared to their previous place of residence, the respondents most positively rated the environmental benefits of living in the countryside, whereas economic factors, especially insufficient sewage and energy infrastructure, in addition to poor services and transport, were downvoted. The results therefore imply the need for better planning of suburban settlement patterns that takes account of the availability and development of the infrastructure network. The settlement dispersion, as shown through spatial studies, leads to higher unit costs, which generate higher public services costs and thus increasing local expenditures.

Keywords: migrations; determinants of migration; migrations from the city to the countryside; economic factors of migration; environmental factors of migration

\section{Introduction}

The issue of migration from cities to suburban zones is becoming a common subject of research. This is due to a high level of development in an increasing number of countries, which boosts population deconcentration in highly urbanised areas [1]. Overpopulation and urbanisation processes lead to the economic effect of congestion, which is associated with, e.g., limited access to free goods and some public goods, especially those of an environmental and spatial nature. This effect encourages people to improve their living conditions, including "escape" from overcrowded and polluted city centres to areas with better environmental conditions. Suburbanisation and urban sprawl are becoming common across the globe (also in less developed countries). Nonetheless, these phenomena have specific characteristics in various regions. 
Areas of particular interest include Central and Eastern Europe, in which the freemarket processes stimulating suburbanisation were non-existent for almost half a century (1945-1989) [2]. These countries did not experience the counter-urbanisation phase, which was characteristic of Western countries in the 1970s and 1980s. Nevertheless, some processes and forms of suburbanisation in Poland existed, but were limited to a relatively small population [3]. Forced migrations from peripheral regions to the areas surrounding the cities were an interesting phenomenon, which occurred due to the lack of access to administrative residence registration, especially in Warsaw [4].

After World War II, internal migrations in Poland were dominated by migrations from the countryside to the cities. The reason for their occurrence was so-called forced industrialisation, which was preferred by the communist authorities, especially in large and medium-sized cities [5]. As a rule, the perception of the city was that it was an attractive place to live compared to the agriculturally backward country. This was especially due to a higher standard of living, less onerous working conditions, and social advancement, including the possibility of acquiring an education [6].

After the fall of the "Iron Curtain" in 1989 and the restoration of market mechanisms, most migrations were still taking place from country to city, although, starting in the 1980s, that process slowed due to the strong economic crisis after martial law (1981), and the housing and construction crisis. During the economic transformation, the village became a buffer, limiting the rate of the rising unemployment [7]. This changed at the end of the 1990s, when internal migrations in Poland began to be dominated by the city-to-countryside direction [8], the essence of which was the emergence, on an unprecedented scale, of displacements from city centres in the centrifugal direction to extensively developed external zones (the so-called internal suburbanisation) or beyond the administrative city limits. This was linked with the emergence of a growing group of people with a higher financial status, who wanted better housing and environmental standards, and was also due to increased environmental awareness $[9,10]$.

In the past 30 years, population growth in Poland's suburban areas has been quite systematic. Their share in inflows (i.e., in registration of residence) increased from $17 \%$ (1989) to $32 \%$ (2019), with the fastest increase until 2010. Since then, that share has remained at the level of approx. 30\% (Figure 1). However, the role of differently sized cities has changed. The importance of small and medium-sized towns and-to a slightly lesser extent-large ones decreased, except for the so-called "Big Five". In the case of these five most attractive metropolises (Warsaw, Cracow, Poznań, Tricity, and Wrocław), their share in the recorded inflows over the last three decades has doubled (from $7 \%$ to nearly $15 \%$ ). It is important to note that "long-distance" migrations are relatively rare, and they are related to the counter-urbanisation phenomena-the share of moves from large cities to typically rural areas (except suburban areas) in 2019 amounted to just over 3\% of all registered flows.

It is commonly assumed that the development of suburban areas is the next phase of the wider urbanisation process, although Poland has its own distinct specificity [11], related to, e.g., the transitional nature of urban-rural areas [12]. The pace of this process in relation to individual centres is irregular [13]. Nevertheless, it has been observed that suburbanisation occurs in virtually all types of urban centres: large [14], medium, and small [15].

The reversal of the net migration rate was highly diversified and noticeable chiefly in municipalities directly adjacent to large cities, where it was important to facilitate migrants' daily commutes to the city, which usually was the location of their professional activity [16]. This trend is still maintained and is now becoming even more visible than previously. Moreover, since around the middle of the first decade of the 21st century, it has been associated with increasingly smaller towns [15]. It is noteworthy that the actual level of urban-rural migration in Poland is much higher than the number recorded by Statistics Poland based on registration data, because not all residents report to the municipal offices within the jurisdiction of the villages they live in, and they do not do so immediately after settling in. Failure to register the residence of those coming from cities often overlaps with 
failure to deregister by people who have left the countryside (in various directions), which means that the registered net migration rates in suburban areas only to some extent reflect the intensity of population migration [17].

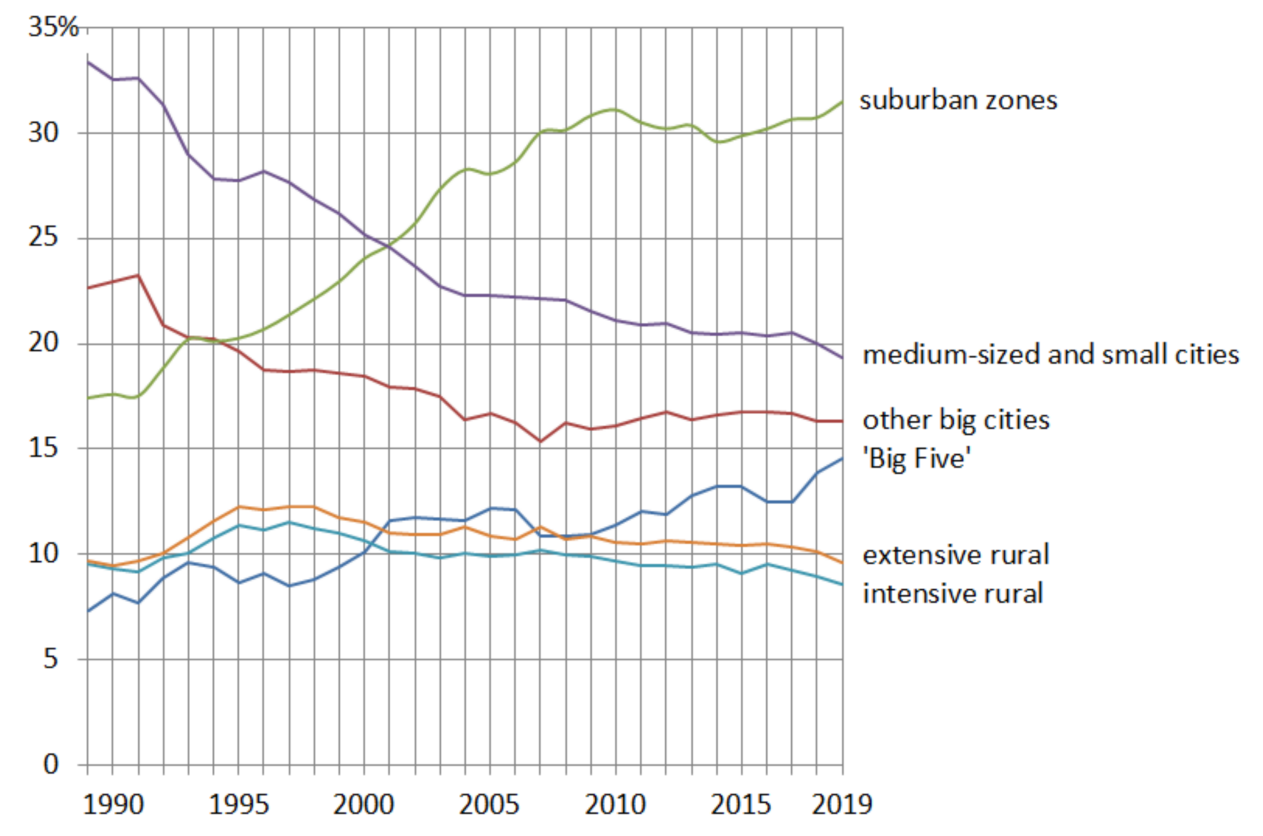

Figure 1. Share in registered inflows in Poland in 1989-2019 of different types of areas (communes). Source: based on migration matrices of Statistics Poland.

Most of the studies on the factors determining migrations from cities to rural areas conducted to date have not focused on extracting economic and environmental factors or determining the role of individual factors in those decisions. Furthermore, they have not analysed the issue of differences in motives and directions of migration. The identified research field attempts to undertake analyses to expand knowledge in this field.

Overall, the aim of this study was to identify the latest factors defining contemporary migrations from the city to the countryside, including the determination of the role of environmental and economic factors. The authors of this study asked the following research questions:

(1) Which factors determine migration from urban to rural areas?

(2) What role do environmental and economic factors play in urban-rural migrations?

(3) Which factors trigger migration and which determine its direction?

In an effort to answer these questions, three research perspectives were adopted in the article: geographic and spatial; economic migration theories; and environmental economics.

The article firstly analyses determinants of the development of suburban zones and the process of migration from cities to rural areas in the historical, economic, and environmental context presented in the Polish and global literature. In general, the authors focus on the Polish context of the issue. In the following section, the methods are characterised. Then the results of the research are presented. In this section, the authors focus on the most important determinants of migration from cities to rural areas, and the choice of particular directions (the village). In the next section we discuss our findings in the relation to the existing literature. Finally, the conclusions include a summary of the most important findings, directions for future research, and recommendations for spatial policies.

\section{Literature Review}

\subsection{Historical Context of Suburbanisation}

Migrations from cities towards rural areas are associated with the process of urban sprawl, which is particularly characteristic of the largest urban agglomerations [9] for 
various reasons. Due mainly to the urbanisation delay in Poland [18], these processes have been taking place only since the mid-1990s [19]. For instance, in Great Britain, this process was studied in the 1930s, when a significant loss of agricultural land on the outskirts of London was noticed as a result of the city's sprawl [20]. In the USA, the growth of cities was rooted in the escape to the suburbs. It started on a large scale in the 1950s, during the period of strong industrial development and related income increase, which was also the period of post-war population growth and government incentives (Servicemen's Readjustment Act from 1944). During that time, people began to live outside city centres, e.g., to avoid traffic, noise, and the increasing crime rate [21,22]. It was enabled, in particular, by the development of the automotive industry and the system of new interstate motorways [23]. One of the reasons for migration from the city to the countryside was also the lower cost of living than in large cities [24,25]. Nonetheless, the conducted research confirmed that the predominant reasons behind moving to the countryside were features attributed to rural areas, such as peace and quiet, landscapes, and recreational opportunities [26-28].

In Poland, the process of suburbanisation and general changes in the city's surroundings were initially the subject of the interest of geographers. As urbanisation developed rapidly after World War II, a relatively large number of works emerged in the fields of settlement morphology, changes in settlement systems, and demographic processes, including migration [29]. Those issues were also quite often discussed in the research of sociologists who studied, inter alia, changes in the lifestyle of rural residents [30,31], leading to the development of urban style features [32-34]. In the subsequent years, this phenomenon was studied from an increasingly broader perspective, i.e., economic, urban, natural, geodetic, engineering and transport, agronomic, etc. [23,35-37].

In the last decade, research into the city surroundings in Poland has been conducted increasingly frequently and has been focused on the issues of life quality. This results, among others, from the strong dispersion of buildings in suburban areas of cities, generating spatial chaos and a significant economic cost of service [38,39].

Slightly less frequently than in previous decades, the topics of population and migration [13], morphological [40] and functional changes, e.g., service and industrial [41], and changes in agriculture have been discussed. New areas of interest have emerged, e.g., public space [42] and revitalisation [43], which are significant in the context of environmental issues. In view of the considerably large number of works on suburbanisation (mostly in the Polish language), studies are being conducted which strive to indicate model approaches, e.g., typological [42].

The need for research in this direction is reflected by the intensification of negative phenomena in the suburban zones in Poland in terms of quality of life and human-environment relations. Not only does it have strictly scientific meaning, but it also has great practical significance, which is particularly important in view of the ignorance and underestimation of these fundamental human life and environmental protection issues by decision makers [44]. Of particular interest is the answer to the question of whether the society shows a noticeable deterioration in the quality of life in light of objective indicators (e.g., commuting time, infrastructure maintenance costs, access to environmental goods), in addition to whether this is reflected in the decisions of migrants regarding the change in their place of residence.

\subsection{Migration Factors in Light of Economic Theories of Migration}

In general, economic factors play a key role in the migratory movements of the population. The first migration studies based on empirical findings showed that the most significant motive for changing the current place of residence was the desire to improve living conditions [45], which stimulated the formulation of the concept of "push" and "pull" between the source and destination areas of migration [46]. Despite the passage of time, the concept of push-pull is now deemed to be the best explanation of the motives behind population mobility related to the change in their place of residence (in the absence of catastrophic events, e.g., wars), similar to Ravenstein's laws of gravity. In the case of 
the objective migrations from cities to the countryside, the suburban zones located close to the cities (gravity factor) are an attractor ("pull" factors), which lure the population, in contrasted to the "push" forces, which drive the population out of the city centres and outer zones.

The economic perspective of the internal migration analysis taking place from urbanized areas towards rural areas can also be outlined by extending the assumptions of the neoclassical theory of migration, initiated by Michael Todaro $[47,48]$. In the neoclassical approach, the migrant is perceived as a rational entity, who takes the decision to migrate or stay in the current place based on the balance of benefits resulting from the move and the costs incurred. From the microeconomic perspective, the neoclassical theory of migration assumes that the migrant, by changing their current place of residence, aims to maximise (or at least increase) their expected benefits (utility, satisfaction). Thus, the decision to move is based on an individual cost-benefit calculation and is contained within a contextual framework [49].

\subsection{Socio-Economic and Infrastructure Causes of Migration}

Among the benefits and costs of migration from urban to peripheral areas, there may be benefits and costs that are objective in nature (e.g., travel costs, rent), but also subjective benefits and costs resulting from the distinctive characteristics of an individual and their value judgement of particular elements improving or diminishing their well-being [50]. The decision to move will therefore result from individual preferences regarding, e.g., housing, costs of living, various elements of life quality, communication infrastructure, and access to green areas, in addition to family ties [25,51-53]. Furthermore, it is emphasised that the balance of costs and benefits made by a person when making a decision to migrate should include not only the benefits and costs actually obtained/incurred and evaluated by that person, but also a number of alternative costs related to leaving their current location, and concerning both the real economic benefits lost (loss of some income, access to infrastructure), and those non-economic costs that are more difficult to measure, e.g., related to separation from family or place of origin [50]. It also seems important to underline that decisions on migration always lack complete knowledge and can only be rational in terms of methodology. Hence, the assessment of the migration balance may take place differently before and after it. It may also look different from the perspective of various members of the migrating household, whose goals and preferences may vary. Despite the multitude of factors influencing migration from the city to the countryside, it is highlighted that a significant contextual factor is the objective changes in the real estate market. It is noted that rising property prices (disproportionate to income) and the cost of living in urban areas may play a key role in deciding to move to peripheral areas, characterised by more affordable prices [54]. It can be assumed that changes in the relationship between real estate prices and changes in wages and salaries may both weaken/suppress and intensify migration.

The theoretical approach proposed by Georg J. Borjas, based on the concept of human capital [55] and directly related to the considered neoclassical theory of migration [49], also seems significant in the description and analysis of internal migrations towards rural areas. In this context, migration is a form of investment in human capital and heads towards places where the potential, expected return on investment exceeds the costs incurred. In this approach, the considered costs also include not only monetary costs, but also nonmonetary costs, such as alternative costs, related to, e.g., travel time and lower costs of living in rural areas, and mental costs resulting from a change in the environment [56]. The research conducted to date has shown that, in the case of migration from the city to the countryside, migrants often decide to change their current place of residence, guided by the non-economic benefits of living in the countryside, thus foregoing the economic and infrastructural benefits of living in urban areas [57].

The impact of the considered economic determinants of migration shows significant discrepancies in terms of the socio-demographic characteristics of migrants. Therefore, 
internal migrations from the city to the countryside are a selective process, e.g., due to aspects including age, income, family situation [55], and education. It was empirically proven that such migrations are much more often undertaken by people with third-level education $[58,59]$. Furthermore, research shows that people from the youngest age group are characterised by greater flexibility in choosing their place of residence. These migrants move more often than others for employment reasons, and the development of transport infrastructure and new technologies (remote work) reduces their potential costs related to daily commuting [51]. However, for middle-aged individuals, the decision to migrate is more often implied by their family (or the family growing bigger) and housing situations (the need to have a larger living space) [51]. It seems that the economic factors of internal migration towards peripheral areas are the least important for people from the oldest age group who choose a new location more often for family reasons (the need to be closer to family and friends) or for convenience (willingness to commune with nature, spending free time in the bosom of nature) [51,60]. Nevertheless, attention is drawn to the increasing role of lower living costs in rural areas as an important driver for migration of elderly people at retirement [61].

\subsection{Determinants of Migration from the Perspective of Environmental Economics Theory}

In addition to economic determinants, contemporary research on internal migration also increasingly frequently takes into account environmental (including air quality and climate change) and location factors that may influence the decision to migrate to rural areas [62]. This is consistent with the growing discrepancy observed in highly developed countries since the 1970s and, in a broad sense, the deteriorating quality of life [63]. The tendency to move to suburban and peripheral areas can also be explained by the growing inclination to pay for environmental living conditions as a higher-order good that can be afforded only at a certain level of income and knowledge. This tendency occurs when there is an increase in income [64].

The role of environmental factors in migrations from cities to the countryside can be seen in examples such as counter-urbanisation [65,66], urban sprawl [67], suburbanisation [68], and amenity migration [69].

The significance and role of various environmental factors undoubtedly depend on the areas where migration takes place [70]. Factors of an environmental nature can both deter and attract migrants [71-73].

The concept of amenity migration is particularly noteworthy. It assumes that the factors motivating individuals to migrate (including migration from the city to the countryside) are the ecological values of the destination [72,74-77]. In this case, the reasons for moving are not of an economic nature or they are not primary [72,76]. Migration to the countryside, including amenity migration, may in particular consist of permanent relocations to places with specific environmental values $[77,78]$. Permanent residence in the countryside may be preceded by recreational trips to a given area or owning a second home in that area used by certain city dwellers during time off work or by retirees $[72,79,80]$.

The environmental factors pushing migrants out of the city are related - most generally - to environmental problems in cities (see also [81]). These problems include, in particular, air pollution and smog formation, noise, street congestion (congestion), unsatisfactory urban standards of the surroundings, including the lack of green and blue areas [82]. It appears that, at the present time, the factor stimulating migration from cities to the countryside may be the post-pandemic reality. There are already many studies showing strong urban-to-rural movements during the peak waves of the pandemic (e.g., [83]).

Migrants can be attracted to the countryside by the natural environment values, either real or expected $[71,84]$, which are the object of desire of many inhabitants of ecologically degraded cities [85]. The environmental values of villages craved by migrants may include, for instance:

- cleaner air [68];

- less noise [70]; 
- $\quad$ slow pace of life [86];

- $\quad$ proximity of nature [86] — green areas, forests [70], bodies of water [87];

- $\quad$ outdoor recreation [88-90];

- high biodiversity [81];

- own garden [70], allowing for relaxation or pursuing one's passions, e.g., gardening [91];

- the attractiveness of the landscape, which can be a source of aesthetic experiences [92];

- quality of life [81].

Particularly interesting in this context is the example of surveys from Hungary, showing the development of so-called community gardens in suburban areas of cities, combining recreational, social, or economic-health functions (the use of "organic food") [93].

The values of the natural environment in the countryside, including the attractive landscape, may certainly affect real estate prices and decisions to move. Land or housing prices may be higher in areas of particularly high aesthetic value or-more broadlythose areas providing significant benefits to residents in the form of cultural ecosystem services [94].

Environmental values may be of paramount importance to families with children, as the children's parents want to raise them in better environmental and health conditions [70,95]. The resources of the natural environment in the countryside may also allow for additional activities (also for profit, e.g., agritourism farms), such as cheese production, bread baking, herb harvesting, or animal breeding [91,92].

The growing ecological awareness may influence the phenomenon of ecological migration [96]. It should be noted, however, that the existing and new countryside inhabitants may [96] perceive the advantages of the local environment in a slightly different manner. The existing village dwellers may treat the environment-especially if they are farmers-as an economic resource and production factor and "a force beyond their control, which is life-giving, but also threatening" [92]. New residents, striving to meet their recreational or aesthetic needs, may be disturbed by the environmental inconveniences associated with running traditional businesses in the countryside. Animal breeding or the operation of machines used in agriculture can be a source of unpleasant odours and noise [91].

Research on phenomena related to migration triggered by environmental concerns has been conducted in different countries and by various authors. The direction of migration influx has been found to be toward, for instance, mountainous areas, such as the Andes in Argentina and Chile [97], the Alps in Austria and Italy [97], the Šumava Mountains in the Czech Republic [81], the Tärna Mountains in Sweden [98]; protected areas or areas near protected areas, such as Bohemian Switzerland in the Czech Republic [99] or peri-urban areas of Wroctaw in Poland [100]; and coastal areas, such as hinterlands of Melbourne in Australia [101] or coastal Maine in the United States [102]. A relatively new trend in Central and Eastern Europe is so-called entrepreneurial migration from cities to the countryside [103].

\section{Methodology}

In this research, the group of respondents was made up of people who migrated from the city of Wrocław to the surrounding rural areas in the Lower Silesia Voivodeship. The respondents were village dwellers living in the poviats (administrative districts) surrounding Wrocław, i.e., the Średzki, Trzebnicki and Wrocław poviats, to which they moved from Wrocław directly $(86 \%)$, or after working and temporary dwelling or studying in the city, and coming from other cities in the region or other places in Poland. The selection of the research area was determined by its features-the Wrocław agglomeration is one of the five most dynamically developing in Poland and has model features of a typical large agglomeration surrounded by rural areas. The empirical study was conducted within one calendar year, 2019, and involved those who had moved from the city to the countryside. The survey was finished before the COVID-19 pandemic. Therefore, it can be stated that the pandemic did not have any impact on the responses provided. 
The survey could not be designed as representative research, because the existing database captures only a part of migration, i.e., only the part which is formally reported in the registration office as a change in a place of residence. A significant (and, it is worth emphasizing, unknown in terms of size and structure) part of the migration from cities to rural areas has not been reported in the registration office, or such migration is reported with considerable delays [104]. As a result, no sampling frame-based Polish database related to the studied issue can be constructed. It was considered, therefore, that in terms of the indeterminacy of the population, non-random sampling is appropriate. This mainly impacted the rejection of the CATI method and the engagement of snowball sampling in the design of the research [105].

Snowball sampling was first used by researchers to study the structure of social networks. Although it is still engaged in the research on the structure of social networks, over the last few decades, the method has largely transformed "into ( . . ) ] an expedient for locating members of a (difficult-to-reach) population" [106,107].

Due to the aforementioned arguments and the limited research budget, 13 individuals were chosen as research participants who recruited other participants. They represented 13 villages located around Wrocław: Radwanice, Nadolice Wielkie, Smardzów, Lutynia, Żurawiniec, Zajączków, Siemianice, Osola, Pietrzykowice, Ramiszów, Śliwice, Jeszkowice, and Smolec. Research participants were asked to indicate other well-known participants who changed the place of residence from a city to particular suburbia. In total, 164 questionnaires were completed during the period.

The study used an interview questionnaire consisting of 15 research questions and a metric. It was developed in three stages: first, using the authors' experience of more than a dozen previously conducted studies, on the basis of discussions among authors, a prototype questionnaire was created. It contained mainly open-ended questions. Second, in 2019, a pilot study was conducted. This made it possible to refine/modify the questionnaire, to create/complete the range of analysed issues, and provide the answers obtained in the survey. The questions additionally could be reformulated into those with a closed or partially open answer. During the third stage, the final version of the questionnaire was used in the study. It consisted of 15 questions and a metric extracting six demographic and social characteristics of the respondents. The questionnaire referred to the place of origin and the length of stay in suburbia; the reasons for migration and the factors determining its direction (specific location); the type of residential property before and after migration; sources of income; the place of economic activity after urban-rural migration; the means of transport in commuting to the city; the location of various areas of activity and the usage of infrastructure in the place of origin and the current place of residence; a general assessment of the migration; a specification of the advantages and disadvantages associated with changing the place of residence; and intentions for further mobility. Due to the objectives and planned structure of the article, only some of the answers are presented here.

The research design and flow process are illustrated in Figure 2. 


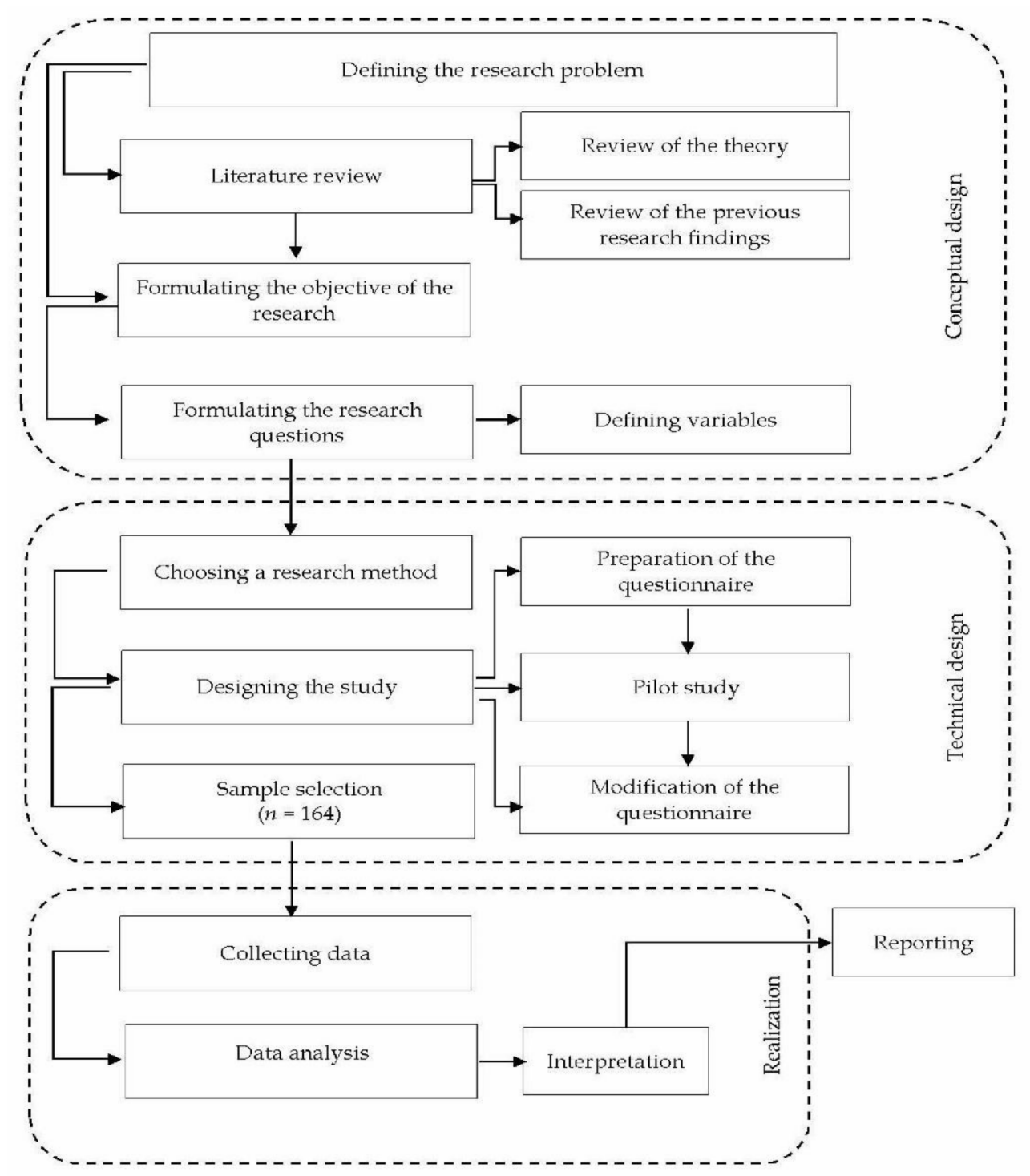

Figure 2. Research methods and processes.

\section{Results}

\subsection{Basic Socio-Demographic Attributes of the Respondents}

Based on the previous research it was assumed that residents of suburbs share similar social characteristics, such as mobile working age, economic activity, relatively high education and income, marital and informal relationships, and the preferences to migrate to particular villages near the same centre. This was proved by the survey. As was previously mentioned, responses were received from 164 respondents (102 women and 62 men) representing various households. The most numerous group comprised people aged 31-40 (30.5\%), and people aged $41-50$ (29.9\%) constituted an almost equally large group. Moreover, $18.3 \%$ of the respondents were people aged $18-30,14 \%$-people aged $51-60$, and the least numerous group comprised those over 61 (7.3\%). Almost three-quarters of the respondents had tertiary education $(73.2 \%)$, one-quarter had secondary education, and less than $2 \%$ had only primary education. Most respondents were registered at their place of residence $(57.3 \%)$, but a significant proportion of the respondents were also people who have not registered at their new place of residence and are still registered in the city they moved from, i.e., Wrocław (18.3\%); $3.7 \%$ of the respondents are registered elsewhere, and $20.7 \%$ of the respondents did not answer this question. 


\subsection{Reasons for the Decision to Move from the City to the Countryside}

The first of the analysed issues related to the reasons for moving from the city to the countryside (Figure 3). This question in the questionnaire was semi-open and the respondents could indicate more than one answer and/or formulate it themselves. More than half of the respondents indicated their wish to have a garden and their own recreational space as the reason for moving from the city to the countryside (53.7\%). Moreover, the respondents quite often mentioned air pollution, noise, traffic congestion, and scarcity of space in the city (43.9\%). The two most frequently indicated reasons for making a decision to migrate from the city to the countryside can be classified as environmental factors, the first of which can be treated as a factor attracting people to the countryside, and the second as pushing them out of the city.

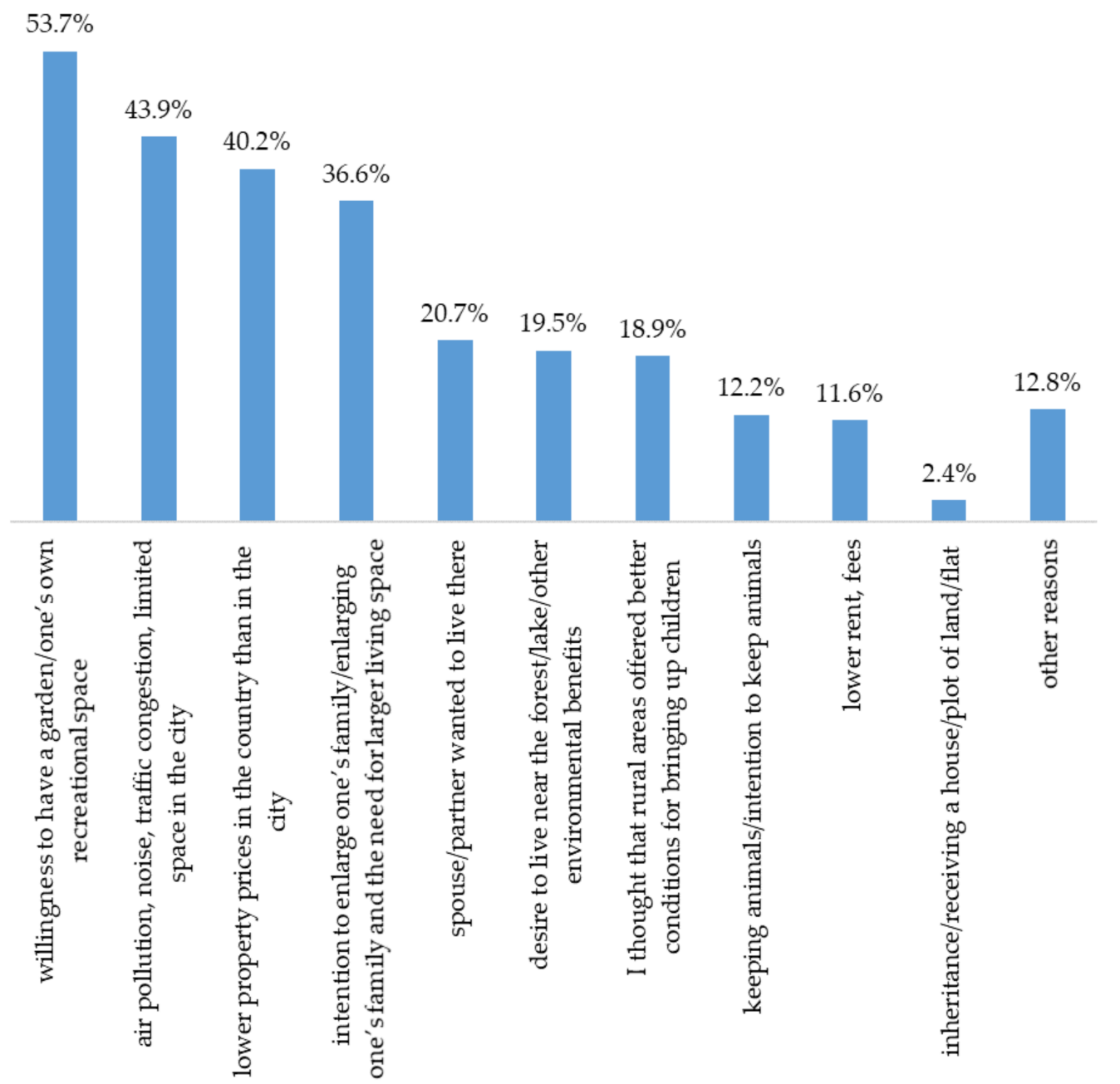

Figure 3. Reasons for moving from the city to the countryside. Source: own study based on research esults.

In third, in terms of the frequency of indications by the respondents, was the economic factor, i.e., lower real estate prices in the countryside than in the city $(40.2 \%)$, which can also be related to another reason impacting the decision to move from the city to the countryside. It was quite frequently indicated by the respondents and had, in a sense, an economic nature, i.e., enlargement/intention to enlarge the family and the need to have more living space $(36.6 \%)$, which can be cheaper in rural areas than in the city.

About $1 / 5$ of respondents indicated the following reasons for moving to the countryside: their spouse/partner wanted to live there (20.7\%), the desire to live near the forest, lakes/other environmental values (19.5\%), I think that the countryside offers better condi- 
tions for raising children (18.9\%). Less frequently, the respondents selected responses such as: having/intention to have animals (12.2\%) and lower rent/fees (11.6\%). The research results also showed that, for a small portion of the respondents $(2.4 \%)$, the motive for moving to the countryside was having inherited/ been given a house/plot of land/flat. A total of $12.8 \%$ of respondents also indicated other reasons for moving from the city to the countryside, such as willingness to live in the countryside, rural climate, moving to one's husband's house after getting married, desire to live in a single-family home, and taking care of the parent/parents.

To highlight the impact of environmental factors in relation to economic factors, in terms of the respondents' decisions to move from the city to the countryside, the abovementioned factors are listed in Table 1. Economic, environmental, and other factors were also distinguished. Additionally, they were qualified in line with the assumptions of the push-pull theory, in relation to factors of an attractive, pushing, and indifferent nature. The sum of indications of narrowly understood environmental factors amounted to $148.2 \%$ (of which $104.3 \%$ were indications of pull factors, and $43.9 \%$ of pushing factors), whereas factors of an economic nature amounted to $90.8 \%$, and those motives were rather of a pulling nature.

Table 1. Reasons for moving from the city to the countryside, broken down into economic, environmental, and other.

\begin{tabular}{|c|c|c|c|c|}
\hline $\begin{array}{c}\text { Type } \\
\text { of Factor }\end{array}$ & $\begin{array}{l}\text { Nature of the } \\
\text { Impact }\end{array}$ & Factor & $\begin{array}{c}\% \\
\text { Indications }\end{array}$ & $\begin{array}{l}\text { Total } \\
\text { Indications }\end{array}$ \\
\hline \multirow{4}{*}{ Economic factors } & \multirow{4}{*}{ Pull factors } & lower property prices in the country than in the city & $40.2 \%$ & \multirow{4}{*}{$90.8 \%$} \\
\hline & & $\begin{array}{l}\text { intention to enlarge one's family/enlarging one's } \\
\text { family and the need for larger living space }\end{array}$ & $36.6 \%$ & \\
\hline & & lower rent/fees & $11.6 \%$ & \\
\hline & & inheritance/receiving a house/plot of land/flat & $2.4 \%$ & \\
\hline \multirow{5}{*}{ Environmental factors } & \multirow{4}{*}{ Pull factors } & $\begin{array}{l}\text { willingness to have a garden/one's own } \\
\text { recreational space }\end{array}$ & $53.7 \%$ & \multirow{5}{*}{$148.2 \%$} \\
\hline & & $\begin{array}{l}\text { desire to live near the forest/lake/other } \\
\text { environmental benefits }\end{array}$ & $19.5 \%$ & \\
\hline & & $\begin{array}{l}\text { I thought that rural areas offered better conditions } \\
\text { for bringing up children }\end{array}$ & $18.9 \%$ & \\
\hline & & keeping animals/intention to keep animals & $12.2 \%$ & \\
\hline & Push factors & $\begin{array}{l}\text { air pollution, noise, traffic congestion, limited space } \\
\text { in the city }\end{array}$ & $43.9 \%$ & \\
\hline \multirow{2}{*}{ Other } & \multirow{2}{*}{$\begin{array}{l}\text { Push, pull and } \\
\text { neutral factors }\end{array}$} & spouse/partner wanted to live there & $20.7 \%$ & \multirow{2}{*}{$33.5 \%$} \\
\hline & & other reasons & $12.8 \%$ & \\
\hline
\end{tabular}

the sum does not add up to $100 \%$ because respondents could indicate more than one answer (also in the further tables and figures). Source: own study based on research results.

Factors such as "my partner wanted to live there", which was indicated by every fifth respondent, also need to be considered separately. These factors suggest that a significant portion of the migrating couples and entire families were inspired by one of the respondents, whose influence on the move was decisive or at least crucial. It is easy to guess (although it has not been researched) that the role of this factor (forcing migration by one family member) was more significant, because it is likely (not specified in the research) that some respondents played a leading role in migration by persuading their less willing partner to move.

\subsection{Reasons for Choosing the Place of Residence}

Another analysed issue concerned the reasons for choosing the direction of migration, i.e., the reasons for choosing a specific (and not any) village to which the respondents decided to move. The question on this issue had a semi-open form, where the respondents could select/complete/provide several answers. According to the answers of the 
respondents (Figure 4), the most frequently mentioned factors were of an economic nature. More than half of the respondents indicated that the choice of the village they moved to was determined by the proximity to the city/workplace/business (53\%). The location of the village to which the respondents moved in relation to the place where their professional/educational activity and/or social, cultural life, etc., took place, was treated as an economic factor, as this location may involve the necessity of frequent/daily travel to and from the city, which can generate many costs, including financial, real, and alternative (e.g., time lost). The economic factors also included the second most frequently mentioned answer-that's where I found a low-cost property $(41.5 \%)$. When choosing a specific village, the respondents relatively often paid attention to whether the selected location had good transport links (21.3\%). That factor was also classified as economic, in relation to the time needed for commuting and to the costs (including alternative costs) of commuting.

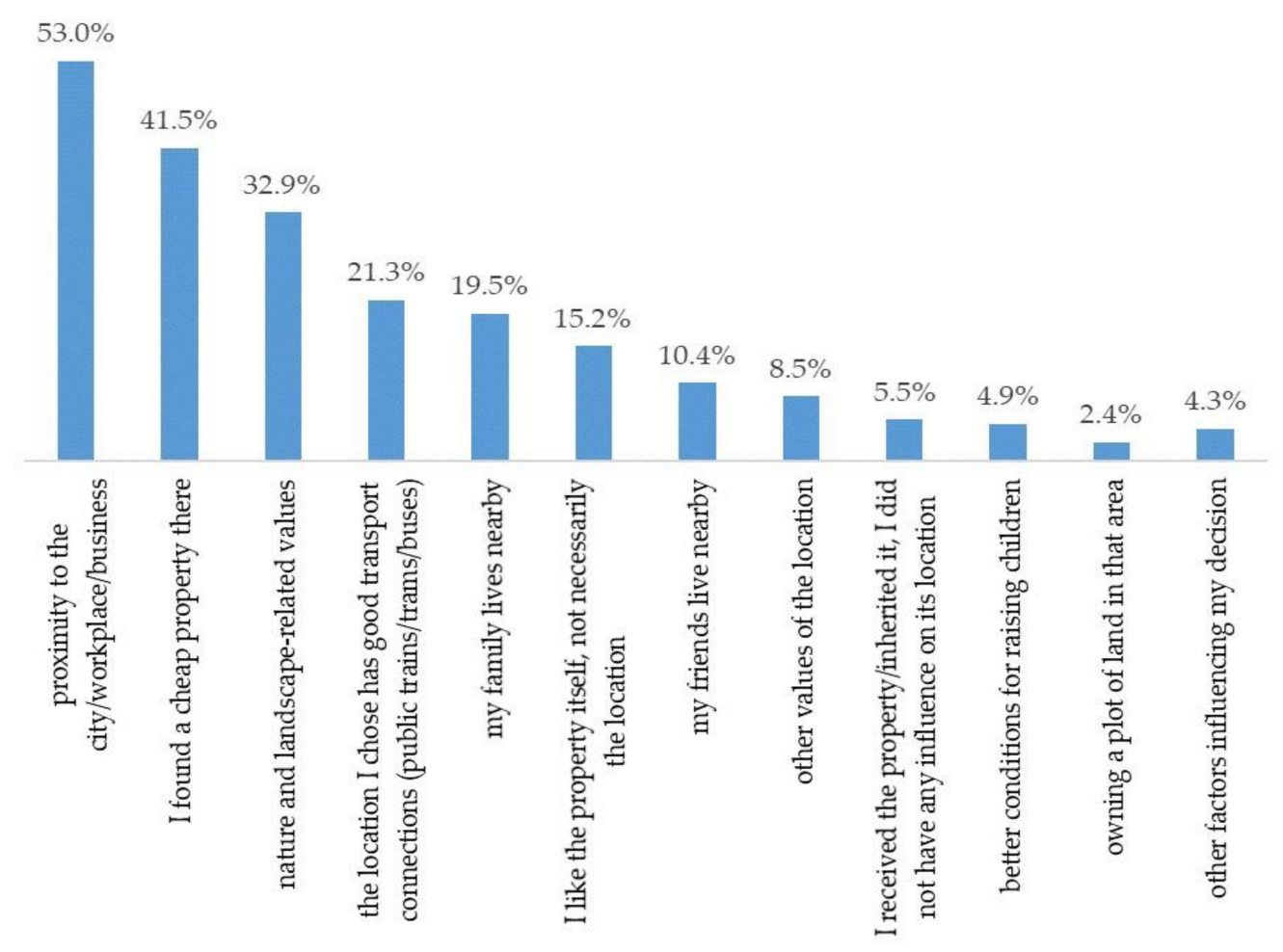

Figure 4. Reasons for choosing a specific location (village). Source: own study based on research results.

Environmental considerations, which were crucial for choosing the direction, were less frequently indicated. The most common answer was the natural and landscape values indicated by every third (32.9\%) respondent. A significant portion of the respondents also chose the following answers: family lives nearby $(19.5 \%)$ and/or friends live nearby $(10.4 \%)$.

A share of $15.2 \%$ of the respondents chose the answer-I liked the property itself (not necessarily its location) - which may indicate that, while living in a given village, the respondents did not analyse other factors characterising a given location or they were less important for them. Among the reasons for choosing a specific village to which the respondents migrated, $8.5 \%$ of them indicated other advantages of the location, and the most often mentioned criteria were safety and peace. Part of the population surveyed lived in a given village without having any influence on choosing their location, because they received/inherited a given property $(5.5 \%)$ or already owned a plot of land in that area $(2.4 \%)$. A total of $4.9 \%$ of the respondents indicated that the choice of a specific location was determined by the belief that there are better conditions for raising children in the countryside. Among other reasons for choosing a given location, indicated by $4.3 \%$ of respondents, were the following answers: a house facing south; good infrastructure in the 
village; I previously lived on that side of Wrocław, so I was looking for a property that would be close.

As in the case of the first analysed question, the reasons for choosing a specific location to which the respondents moved were broken down into factors of a predominant economic or environmental nature, and other (Table 2). It was found that the sum of indications of factors considered to be of an economic nature amounted to $115.8 \%$, whereas the sum of indications of factors considered to be of an environmental nature equalled $37.8 \%$.

Table 2. Reasons for choosing a specific location (village) broken down into economic, environmental, and other.

\begin{tabular}{|c|c|c|c|}
\hline Types of Factors & Factor & $\begin{array}{c}\text { \% of } \\
\text { Indications }\end{array}$ & $\begin{array}{c}\text { Total } \\
\text { Indications }\end{array}$ \\
\hline \multirow{3}{*}{ Economic factors } & $\begin{array}{l}\text { proximity to the } \\
\text { city/workplace/business }\end{array}$ & $53.0 \%$ & \multirow{3}{*}{$115.8 \%$} \\
\hline & found a cheap property there & $41.5 \%$ & \\
\hline & $\begin{array}{c}\text { chosen location has good transport } \\
\text { connections (public } \\
\text { trains/trams/buses) }\end{array}$ & $21.3 \%$ & \\
\hline \multirow{2}{*}{$\begin{array}{l}\text { Environmental } \\
\text { factors }\end{array}$} & $\begin{array}{c}\text { nature and landscape-related } \\
\text { values }\end{array}$ & $32.9 \%$ & \multirow{2}{*}{$37.8 \%$} \\
\hline & $\begin{array}{l}\text { better conditions for raising } \\
\text { children }\end{array}$ & $4.9 \%$ & \\
\hline \multirow{5}{*}{ Other factors } & family lives nearby & $10.4 \%$ & \multirow{5}{*}{$31.1 \%$} \\
\hline & other values of the location & $8.5 \%$ & \\
\hline & $\begin{array}{c}\text { received the property/inherited it, } \\
\text { did not have any influence on its } \\
\text { location }\end{array}$ & $5.5 \%$ & \\
\hline & other reasons & $4.3 \%$ & \\
\hline & owning a plot of land in that area & $2.4 \%$ & \\
\hline
\end{tabular}

Source: own study based on research results.

When analysing the reasons most often indicated by the respondents for their decision to move from the city to the countryside and the reasons for choosing a specific location, a certain regularity can be noticed; namely, leaving the city for the countryside is more often determined by environmental factors, generally related to the conditions and quality of life in rural areas, whereas the choice of a particular village is more often determined by economic and infrastructural factors, particularly property prices and opportunities/conditions/travel costs to the city of their origin.

From the perspective of the push-pull theory, it can also be said that in the decisions to leave the city, push factors will play a greater role, and attracting factors will have more significance for the direction of migration. Thus, it can be noticed that this regularity makes these migrations similar to refugee movements, where the mobility itself is triggered by threat/discomfort, whereas in choosing the direction of migration, economic pragmatism is more important. In the case of refugee movements, this has often resulted in refugees trying to flee the endangered area in the first place, but ultimately trying to reach the country/area with potentially the best economic prospects for their future.

Taking into consideration the large number of respondents who included the travel conditions, it can also be assumed that they take into account, at least potentially, additional real and alternative costs related to migration $[50,56]$. 


\subsection{Elements of Living in Rural Areas Assessed Positively and Negatively in Relation to the Previous Place of Residence}

The next two lists pertain to the elements related to living in rural areas, which the respondents evaluate most positively (Figure 5) and negatively (Figure 6) in relation to their previous place of residence. Those questions were open-ended and the respondents could provide more than one item. Due to the similarity of the answers submitted by the respondents, they were grouped and classified into the categories presented in Figures 5 and 6, whereas the elements given by individual respondents are presented in the charts in the other category.

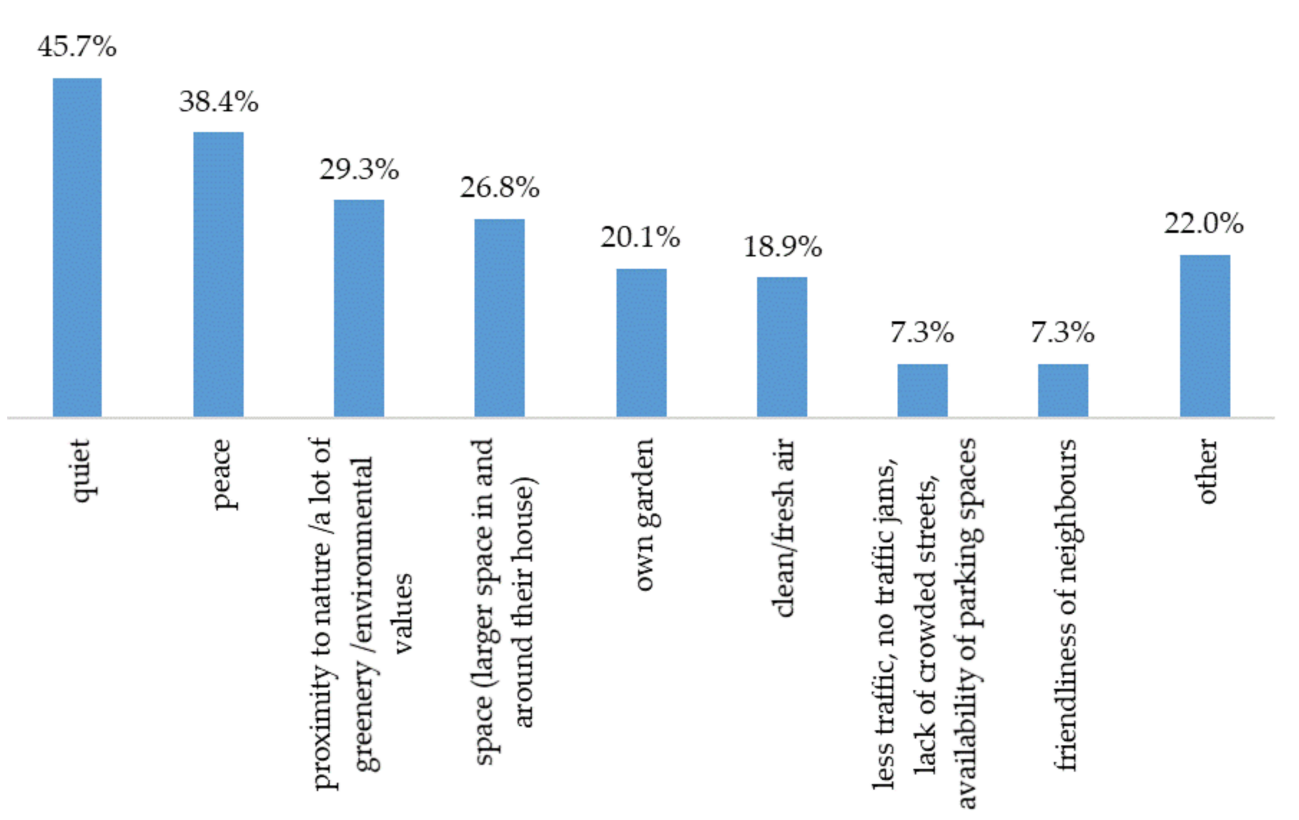

Figure 5. Elements of rural residence assessed most positively in relation to the previous place of residence. Source: own study based on research results.

The research results show that the respondents in their new place of residence value quiet $(45.7 \%)$ and peace $(38.4 \%)$ the most. Relatively often the respondents indicated proximity to nature/a lot of greenery/environmental values (29.3\%) and space (larger space in and around their house) (26.8\%). Every fifth respondent in their current place of residence appreciated their own garden the most $(20.1 \%)$, and $18.9 \%$ of the surveyed participants appreciated clean/fresh air in the countryside. Up to $7.3 \%$ of the respondents more positively evaluated the following aspects, including less traffic, lack of traffic congestion, lack of crowded streets, availability of parking spaces, and friendliness of neighbours as the advantages of living in the countryside, compared to their previous place of residence. Among other most positive elements of living in the country in relation to the city, the participants of the study indicated, e.g., privacy; no next door neighbours; their child spends the whole day outside, not in front of the computer screen; time goes by more slowly; own place for rest and recreation; maintenance costs.

Among the elements of living in the country which were assessed negatively by the respondents in relation to their previous place of residence quite frequently (Figure 6)were indicated the lack or insufficient number of public and suburban transport connections (buses, minibuses, PKP (Polish State Railways) (22.6\%), and PKS (Polish National Bus Company), in addition to the distance from the city/city centre/shop/work/schools/kindergartens/PKP (Polish State Railways) (18.3\%). These two elements may cause difficulties in reaching the places indicated by the respondents, especially if they do not have their own means of transport. They can also cause additional problems related to the necessity of spending significantly more time to reach the indicated places. Commuting to work is also a significant obstacle for the surveyed people $(7.9 \%)$. Nearly every tenth respondent indicated unpaved 
roads as a negative element of living in the countryside (9.8\%), and $7.9 \%$ of respondents indicated the lack of a sewage system. Among the remaining elements of infrastructure, the respondents negatively assessed the lack of lighting (4.3\%), lack of pavements (3.7\%), and lack of gas installations $(1.8 \%)$ in relation to their previous place of residence. The respondents were also affected by the lack of commercial facilities (5.5\%), cultural facilities $(4.9 \%)$, catering facilities $(4.3 \%)$, and sports facilities (3.0\%). As elements of living in the countryside that were evaluated negatively in relation to the previous place of residence, the respondents also indicated negative interpersonal relations (4.9\%), condition of air in winter $(4.3 \%)$, weaker Internet connections $(2.4 \%)$, a limited range of additional activities for children $(2.4 \%)$, unpleasant smell $(2.4 \%)$, problems with water pressure $(2.4 \%)$, considerable distance from friends and / or family $(2.4 \%)$, and more household chores $(1.8 \%)$. Other elements assessed negatively by the respondents included (9.8\%): difficulties entering the city due to traffic jams; wind; postponed investments; lack of professional medical clinic, bank, ATM, or church.

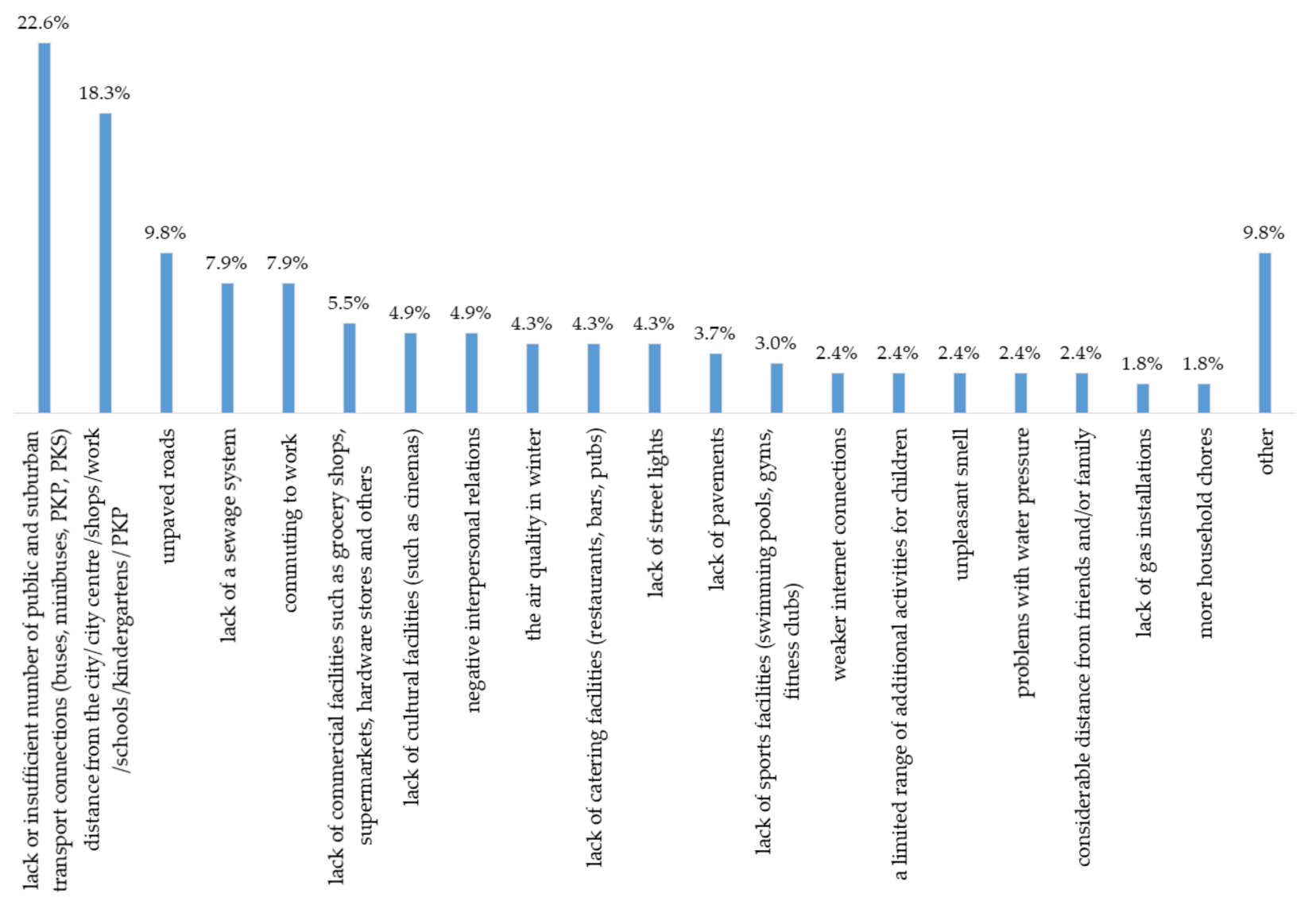

Figure 6. Elements of rural residence assessed negatively in relation to the previous place of residence. Source: own study based on research results.

The answers of the respondents to the question regarding the elements of living in rural areas evaluated most positively and negatively compared to the previous place of residence may indicate that the surveyed migrants most appreciate the elements/values of an environmental nature, which to some extent result from the location of the inhabited property, i.e., peace and quiet. They also appreciate the proximity of nature, greenery, and other environmental values-total indications in that case amounted to over $169 \%$. Much less often they indicated elements/values of an economic nature, which dominate among the negatively assessed elements related to living in the countryside, and which are manifested in the lack or insufficient number of public and suburban transport connections, in addition to 
a significant distance from the city / city centre/shops/work/schools/kindergartens/PKP (Polish State Railways). It can be assumed that a number of problems related to the technical infrastructure reported by the respondents are temporary and can be explained by the fact that the development of infrastructure (roads, sewage systems, lighting, access to energy infrastructure, etc.) cannot keep up with the intensified suburbanisation processes.

It is also worth mentioning that $4.9 \%$ of respondents indicated negative interpersonal relations as the most negative element of moving from a city to the countryside, whereas $7.3 \%$ of respondents indicated kind neighbours as the most positive element in their new place of residence. Therefore, this element most likely depends on experiences in relations with the neighbours and the local community, which may be dependent on different patterns of behaviour of the local community and the newcomers, in addition to the diversity of cultural patterns and attitudes of individual newcomers, who are currently neighbours. This type of local conflict, appearing during the construction of housing estates, was also observed in other studies concerning villages in a similar area [104]. An interesting fact is that a significant number of respondents reported the problem of air quality in winter, probably resulting from the poor quality of fuels and heat sources used in some households, especially those that are poorer or not connected to the heating or gas network. At the same time, four times more respondents indicated clean/fresh air as an element assessed positively, compared to their previous place of residence.

When comparing the factors indicated as determining migration and its direction with the post factum assessment of migration, it should be noted that the negative aspects of migration related to the insufficient infrastructure are not adequately reflected in the respondents' reactions to the factors determining migration and its direction. Thus, a hypothesis can be proposed that, while the respondents in their migration decisions paid attention to the perspective of commuting (potential inconvenience and costs), they did not take into account or appreciate the nuisance related to poorer infrastructure in general. Interviews held with the respondents indicate that it is likely that some of the nuisances (e.g., unplanned or long unpaved roads, repetitive work related to the maintenance of greenery, and nuisance related to neighbouring farms) reported by the respondents were not previously predicted and calculated. This may result both from the fact that most of the respondents had not lived in the countryside before and did not know a number of nuisances characteristic of such areas, especially in the colder season. It may have also resulted in a kind of paradox, expressed in the fact that some of the respondents could not predict the annoying smog in suburban areas related to the failure to connect those areas to the municipal heating network and less rigorous enforcement of heating and fuel regulations used in domestic boiler houses.

Overall, however, it can be concluded that the results of the research do not indicate significant discrepancies between the motives of the migration and the post-migration evaluation. Most likely, such discrepancies are hardly noticeable due to the relatively good (compared to, e.g., foreign migration) knowledge about the living conditions in the place of destination.

As a result, the vast majority of the survey participants were satisfied with the decision to move from the city to the countryside (Figure 7). In retrospect, $67.1 \%$ of the respondents assessed it positively and another $27.4 \%$ rather positively. 


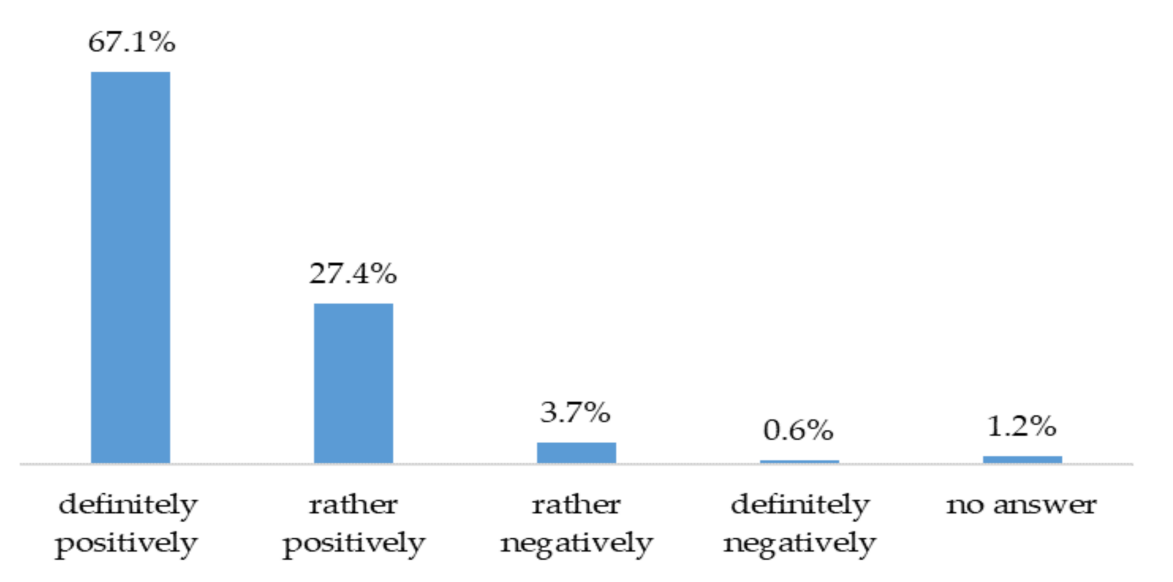

Figure 7. Evaluation of the decision to move to the countryside. Source: own study based on research results.

\section{Discussions}

In this study, we investigated the economic and environmental factors influencing migration from urban to rural areas. The research results indicate some interesting characteristics which can be observed in Poland and in other countries. The first few characteristics refer to the posed research question.

It was identified that urban-rural migration is more often determined by factors generally related to the conditions and quality of life in urban and rural areas. The most common reasons for making a decision to migrate from the city to the suburban zones can be classified as environmental factors, which can be treated as a factor attracting people to the countryside, and as pushing them out of the city. It can be noted that, due to this characteristic, urban-rural migrations are similar to refugee movements, where the mobility itself is triggered by threat/discomfort, whereas in choosing the direction of migration, economic pragmatism is more important.

The research results presented in the article, in addition to those of other research conducted by, among others, E. Zysk [108], show that for the majority of respondents, the main reason for deciding to move from the city to suburban areas was the desire to have space and a place of one's own, to improve their quality of life, and to be close to nature. Another important reason for moving from the city to the countryside indicated by the research was a growing family, and as a consequence, the need to buy a larger flat or build a house in rural areas which, after analysing the costs, prompted the respondents to choose the second option. These findings are in line with other research conducted in many countries in Central and Eastern Europe and Asia. They also identified that movement of the population to suburban areas and villages is driven by efforts to improve the quality of life [109-111]. Similar conclusions can be drawn from studies carried out in Poland-in the functional area of Warsaw [112], Poznan [10], and the Krakow Metropolitan Areawhere migrations from the city to the countryside were undertaken, and were determined mainly by family and environmental factors, and to a lesser extent by typically economic reasons [41]. It should be highlighted that the migrations from Kraków and those from Wrocław analysed in the article differ considerably. The inhabitants of Kraków have been well settled for generations. More often than they are of local origin and much more often have relatives in the city and its surroundings. In the case of Wrocław, its inhabitants moved in almost entirely after World War II, as a result of the resettlement of the Polish population in place of the displaced Germans. Hence, the social networks in Wrocław should be evaluated both within the city and in the city-suburban relation as being weaker than in the case of Kraków.

In terms of environmental factors, migration is strongly influenced by well-recognised (due to being the starting point for the calculation) push factors related to the dissatisfaction with the environmental and spatial living conditions in the city. This conclusion is consistent 
with other previous studies conducted in Poland [10,108,113,114] and abroad [57,115]. The research results which refer to push factor from cities differ from earlier findings of Jargowsky and Park [116] that show that, above all, inner-city crime is a motivating factor for middle-class migration. In the research conducted abroad, the push factors which discourage people to live in cities were less explicit and classified as fiscal and social problems: high taxes, low quality public schools and other government services, racial tensions, crime, congestion, and low environmental quality. Problems observed in cities trigger high-income central-city residents to migrate to the suburbs, which leads to further deterioration of the quality of life in central areas, inducing further out-migration [115]. Features of urban areas which trigger out-migration were also recognised by K. Kajdanek, who highlighted the nuisances and inconveniences that pushed people out of the city, including overcrowding, noise caused by neighbours and their dogs, or high rent [117].

It is also important to highlight that the above-mentioned migration-related motives are more often ascribed to short-distance moves, whereas long-distance migrations are generally determined by typically economic factors $[67,89,118]$. Moreover, it can be assumed that the motives of migration from the city to the countryside also vary, depending on the size of the city acting as the outflow area [119]. This is also confirmed by the authors' pilot studies conducted around smaller urban centres in southern Poland other than Wrocław.

The second identified characteristic refers to economic and transport infrastructure factors triggering migration to a specific location (village). The most common factors affecting the decision to choose specific localities were of an economic nature. Overall, the results proved that economic factors play a key role in the migratory movements of the population - not in a general sense, but when choosing the specific location [51,54].

The respondents primarily indicated the proximity of the village to the workplace and cheap properties. Nevertheless, the current environment of rising real estate prices has even further increased the importance of the cheaper cost of living in rural areas. According to Howard, one of the most important advantages of villages over urban areas is low rent [120]. However, in that study, not only was the level of real estate prices taken into account, but also the overall cost of living. It was found that generated costs for each of six component subindexes-groceries, housing, utilities, transportation, health care, and miscellaneous goods and services-were cheaper in rural areas than in cities [121]. This could be another crucial factor triggering out-migration from cities to urban areas, becoming even more important when inflation is in increasing at its fastest pace in decades. The findings that refer to economic factors of choosing specific localities did not strongly support Williams' [27] assertion that jobs are facilitators rather than the primary reason for migration.

The research results proved that when choosing the place of settlement, adequate infrastructure such as roads and transport facilities was no less important. In this regard, similar findings were reported by K. Kajdanek [117], who, referring to the reasons for the selection of a specific suburban location by the people she surveyed, writes- "It was not based on the hardly measurable and even more difficult intersubjectively comparable categories of beauty, the climate of the place and the elusive genius loci, but the distance from the city (or rather the time it takes to cover it), and the quality of road and technical infrastructure." It has become even more vital during and after the COVID-19 pandemic, when there is higher need for digital technologies in rural areas. A case study of many countries proved that, during the pandemic, rural areas were more resilient to the virus and people had a desire to live in suburban zones more than before. However, when choosing the specific place to live, a crucial determinant is the accessibility of the Internet infrastructure which facilitates remote work and education [122].

Other findings that arose from the research results are the residential satisfaction of migrants. Most of them positively assessed the change of place of residence. The positive assessment of the migration obtained from the respondents refers to the majority of environmental benefits, which are in line with the research provided by Píša and Pandas $[99,123]$. These previous findings indicated, inter alia, improvement of the health 
of inhabitants of suburbia or rural areas. In contrast, the respondents also enumerated elements of living in suburbia that were assessed negatively. A significant part of such inconveniences results from the failure to keep up with the development of technical infrastructure, including road, sewage, and energy systems, in addition to the shortage of public transport, the lack of commercial and service offers, and smog. These results are consistent with those found in other studies $[99,111,124]$ which refer to car dependency, noise, and insufficient infrastructure (transport, sewage systems, and energy).

When considering the residential satisfaction, different studies show that residents of the principal cities in the metropolitan areas do not have lower life satisfaction than residents of suburbs [125]. It has been proved that the residential satisfaction should be measured by many indicators and in different periods of time. It should be emphasised that the recent study proved that residential satisfaction is determined by personal characteristics and individual objectives of migration $[51,126]$. The assessment of residential location may have changed in time due to changes in the composition of the population and because of the greater opportunities for consumers to satisfy their residential preferences [51]. It also seems important to note that the assessment of the migration balance may take place differently before and after it. It may also look different from the perspective of various members of the migrating household, whose goals and preferences may vary $[127,128]$.

In the above context, it is worth paying attention to a number of problems, already discussed in the literature, and which are largely confirmed by the current research. Particular attention is paid to local conflicts of various causes [44,104,129], social inclusion [110], mismatching between transport and settlement systems [130], underdevelopment of transport and energy infrastructure [130,131], landscape defragmentation [132], and air pollution [133]. These pathologies result mainly from defective planning laws, including the jurisprudence of administrative courts [38], in addition to the inefficiency of public authorities [134]. Simultaneously, it is important to underline that the Polish spatial planning system is one of the most complex in Europe [135] and works showing the proper functioning of various systems, e.g., infrastructure, are rare [136].

\section{Conclusions}

\subsection{Research Findings}

The empirical research was based on the economic, geographical, and environmental theories of migration movements. Despite the fact that the study was not representative due to objective limitations, to a large extent, the intended goal was achieved, and some interesting conclusions formulated. Certain characteristics were also indicated that could constitute hypotheses for further research on the topic.

The main findings concern the causes of migration from the city to the countryside and the factors determining their direction, i.e., to a specific location. The contractual division of migration factors and factors involving the direction of migration into environmental and economic influences, which were introduced by the authors, indicated that environmental and non-economic factors more often influenced migration (triggered it), whereas economic and infrastructural factors more often determined the direction of migration, i.e., a specific location of residence outside the city. The respondents would like to live relatively close to the city they left and stay in good communication with it due to their continued work there and the use of some elements of the broadly understood infrastructure. A particular location is also significantly influenced by family and social networks, which are expressed by having relatives and friends in a given location, in addition to being the owner of inherited property. The prices and availability of properties are also of great importance.

The assessment of the migration obtained from the respondents is largely positive, which proves that the positive aspects of the new place of residence compensated for the lost benefits related to permanent residence in the city. It also proves that the respondents evaluated and calculated the consequences of their decision to migrate quite well. Nonetheless, the respondents' indications regarding the positive and negative aspects related to the new place of residence prove that, although their expectations related to the majority 
of environmental benefits from migration were confirmed, they did not fully account for a number of nuisances, and additional obligations, and costs, including alternative ones. A significant portion of such inconveniences results from the failure to keep up with the development of technical infrastructure, including road, sewage, and energy systems, in addition to the shortage of public transport, commercial and service offers.

Among the disadvantages of migration, however, there are also those that the migrants likely did not expect. This applies especially to problems such as pollution of suburban villages caused by smog, which is characteristic of suburban areas in Poland [98]. Generally, this is due to the unavailability of urban heat sources in these areas, forcing the installation of individual boiler houses powered by solid fuels, which influences emissions and exacerbates the issue of smog in the colder seasons.

The above findings are significant due to the nature of suburban (and generally rural) development in Poland, which is excessively dispersed. This necessitates a relatively extensive infrastructure, which in the per capita calculation becomes irrational and ineffective, and sometimes even leads to the inability of service. The aforementioned smog in new suburban settlement areas is often the result of too great a dispersion of buildings and the unprofitability related to building more modern heating systems, which means that households are forced to find individual solutions, i.e., usually coal-fired furnaces. Hence, it is proposed that the promotion of distributed generation solutions [99] is of particular importance for the development of energy in suburban areas (and generally with dispersed settlements). This problem seems to be of key importance for improving environmental quality in countries with dispersed settlements. The problem of energy produced from low-quality sources is not only a problem for the poorest countries, but also for more developed ones where the settlement structure makes it difficult to produce and distribute energy in a more concentrated manner. In Europe, this is particularly true of the most sparsely populated areas in the north of the continent, and mountainous areas.

\subsection{Future Research}

It seems that the evaluation of the rationality regarding the decision to migrate requires more detailed research, for instance, by showing the assessment from the perspective of various family members, for whom it is associated with a different balance of costs and benefits. This evaluation is probably related to the age of respondents, who may have different preferences in terms of spending time. An interesting issue in this regard seems to be, in particular, the way in which the family makes a joint decision to leave, and the issue of the characteristic stratification of life after living in the countryside. Research shows that migrants can participate in economic and social structures in their new place of residence or in the city they come from.

It should be noted that the importance of environmental factors in urban-rural migrations largely depends on the condition and environmental values of specific areas. It can be assumed that such migration-mainly inspired by the environmental factor-will attract the inhabitants of polluted and noisy cities located in the vicinity of particularly appealing rural areas. Therefore, in further work, it is worth taking into account the differences in the environmental values of specific areas and their impact on the decisions made. These studies may also reveal to what extent the migrants' expectations (or individual household members') related to the purchase of a house in a clean and quiet village differ from the experiences gained in their new place of residence.

In the contemporary Polish conditions, one of the most important aspects of the analysis should be the analysis of the effects (economic and fiscal, demographic, environmental and spatial) of migration made from the perspective of the outflow and inflow areas. This applies, among others, to places where income taxes are paid, which in Poland are a key source of municipal budgets [106]. The issue of migrants transferring their taxes and expenses to the new area is crucial for the further development of both the inflow communes and the cities of origin [107], as with the issue of environmental impact and human pressure. However, this has not yet been thoroughly researched. There are also 
new conditions for urban-rural migration, related to the pandemic threat and the search for safer places to live. In the Polish conditions, this may intensify the existing dispersion of buildings around cities and contribute to the increase in spatial chaos.

\subsection{Policy Implication}

Based on the research results, suggestions geared toward policymakers can be made. If the local policy of urban areas is related to maintaining/improving the size of the population and its structure, it should lead to a positive fiscal result, by providing the most attractive areas for settlement inside the city and not outside its borders. This can be achieved in at least three ways: firstly, by adapting certain areas for housing; secondly, by protecting and creating (e.g., eliminating pollution, introducing wooded areas, building water reservoirs, etc.) environmental values in areas designated for residential development; thirdly, by enlarging the size of areas predisposed to housing functions within the city limits. At the same time-as indicated by the studies-choosing a specific place of residence is determined, to a large extent, by economic factors. Therefore, it is better to plan suburban settlement patterns taking account of the availability/development of the infrastructure network and thus reducing costs rather than allowing them to disperse. The settlement dispersion, as shown through spatial studies, leads to higher unit costs generating higher public services costs, and thus increasing local expenditures.

Author Contributions: Conceptualization, R.J., P.Ś., M.P., A.D. and J.R.-M.; methodology, R.J., software, A.D. and J.R.-M.; validation, R.J., P.S., A.D., J.R.-M., M.P. and D.R.-P.; formal analysis, R.J., P.Ś., A.D., M.P., J.R.-M. and D.R.-P.; investigation, A.D. and J.R.-M.; resources, R.J., P.Ś., A.D., J.R.-M., M.P. and D.R.-P.; data curation, R.J., M.P., A.D. and J.R.-M.; writing—original draft preparation, R.J., P.Ś., A.D., M.P., J.R.-M. and D.R.-P., writing—review and editing, R.J., P.Ś., A.D., M.P., J.R.-M. and D.R.-P., visualization, A.D. and J.R.-M.; supervision, R.J. and P.Ś.; project administration, A.D. and D.R.-P.; funding acquisition, A.D. All authors have read and agreed to the published version of the manuscript.

Funding: Wroclaw University of Economics and Business.

Institutional Review Board Statement: Not applicable.

Informed Consent Statement: Not applicable.

Data Availability Statement: Not applicable.

Acknowledgments: Authors would like to thank those who conducted survey: Bochnia Natalia, Czerniatowicz Adrian, Lewicka Marta, Pilszak Wiktor, Skoczylas Dominika, Włodarczyk-Demidowicz Malwina. We would like to thank the reviewers for their thoughtful comments and efforts towards improving our manuscript.

Conflicts of Interest: The authors declare no conflict of interest. The funders had no role in the design of the study; in the collection, analyses, or interpretation of data; in the writing of the manuscript, or in the decision to publish the results.

\section{References}

1. OECD. Cities in the World: A New Perspective on Urbanisation; OECD Publishing: Paris, France, 2020; ISBN 978-92-64-37666-3.

2. Kiril, S.; Ludĕk, S. Confronting Suburbanization: Urban Decentralization in Postsocialist Central and Eastern Europe; Wiley-Blackwell: Chichester, UK, 2014; ISBN 978-1-118-29588-5.

3. Weesep, J.V.; Korcelli, P. Migration and residential mobility in the Warsaw region. In Residential Mobility from Poland to The Netherlands; KNAG: Amsterdam/Utrecht, The Netherlands, 1990; pp. 46-58.

4. Rykiel, Z. Spatial barriers: Concepts, use and an application to intra-regional migration. Geogr. Pol. $1988,54,33-41$.

5. Wróbel, A. Industrialization as a factor of regional development in Poland. Geogr. Pol. 1980, 43, $187-197$.

6. Szymańska, D.; Matczak, A. Urban system and urban population dynamics in Poland. Eur. Urban Reg. Stud. 2002, 9, 39-46. [CrossRef]

7. Korcelli, P. Urban restructuring in East-Central Europe: Selected questions. Geogr. Pol. 1995, 66, 7-12.

8. Kurek, S. Territorial distribution of population change in Poland in the years 1991-2001. Bull. Geogr. Socio-Econ. Ser. 2005, 4, 117-134. 
9. Gutry-Korycka, M. Urban Sprawl. Warsaw Agglomeration Case Study; Wydawnictwo Uniwersytetu Warszawskiego: Warszawa, Poland, 2005.

10. Staszewska, S.; Wdowicka, M. Suburbanisation in Poland in the period of socio-economic transformation. In Cities in Global Perspective: Diversity and Transition; Murayama, Y., Du, G., Eds.; IGU Urban Commission: Tokyo, Japan, 2005 ; pp. 62-71.

11. Krzysztofik, R.; Kantor-Pietraga, I.; Runge, A.; Spórna, T. Is the suburbanisation stage always important in the transformation of large urban agglomerations? The case of the Katowice conurbation. Geogr. Pol. 2017, 90, 71-85. [CrossRef]

12. Korcelli, P.; Grochowski, M.; Kozubek, E.; Korcelli-Olejniczak, E.; Werner, P. Development of Urban-Rural Regions: From European to Local Perspective; Institute of Geography and Spatial Organization; Polish Academy of Sciences: Warsaw, Poland, $2012 ;$ Volume 14.

13. Kurek, S.; Wójtowicz, M.; Jadwiga, G. Functional Urban Areas in Poland. Demographic Trends and Migration Patterns; Springer: Cham, Switzerland, 2020.

14. Gałka, J.; Warych-Juras, A. Suburbanization and migration in Polish metropolitan areas during political transition. Acta Geogr. Slov. 2018, 58, 63-72. [CrossRef]

15. Śleszyński, P. Demographic changes in the functional urban areas in Poland, 2000-2010. Geogr. Pol. 2013, 86, 169-170. [CrossRef]

16. Drejerska, N.; Chrzanowska, M. Commuting in the Warsaw suburban area from a spatial perspective-An example of empirical research. Acta Univ. Lodz. Folia Oecon. 2014, 6, 12-26.

17. Jończy, R. Sytuacja Demograficzna i Zatrudnienie na Obszarach Wiejskich Województwa Opolskiego; Instytut Śląski: Opole/Wrocław, Poland, 2017.

18. Wẹcławowicz, G. Contemporary Poland: Space and Society; University College London: London, UK, 1996.

19. Śleszyński, P. Suburbanization processes in Poland after 1989. Probl. Geogr. 2006, 1-2, 105-117.

20. Gant, R.L.; Robinson, G.M.; Fazal, S. Land-use change in the “edgelands": Policies and pressures in London's rural-urban fringe. Land Use Policy 2011, 28, 266-279. [CrossRef]

21. Resnik, D.B. Urban sprawl, smart growth, and deliberative democracy. Am. J. Public Health 2010, 100, 1852-1856. [CrossRef]

22. Barrington-Leigh, C.; Millard-Ball, A. A century of sprawl in the United States. Proc. Natl. Acad. Sci. USA 2015, 112, 8244-8249. [CrossRef] [PubMed]

23. Zebik, G. Typology of suburban communities in Poland. Bull. Geogr. 2011, 16, 173-188. [CrossRef]

24. Boyle, P.; Halfacree, K.; Robinson, V. Exploring Contemporary Migration; Addison Wesley Longman: New York, NY, USA, 1998.

25. Costello, L. Urban-Rural migration: Housing availability and affordability. Aust. Geogr. 2009, 40, 219-233. [CrossRef]

26. Ploch, L.A.; Cook, C.M. Turnaround migration and theoretical perspectives. Rural Sociol. 1982, 2, 36-44.

27. Williams, A.S.; Jobes, P.C. Economic and quality-of-life considerations in urban-rural migration. J. Rural Stud. 1990, 6, 187-194. [CrossRef]

28. Lopez, R. Urban Sprawl in the United States: 1970-2010. Cities Environ. 2014, 7, 7. Available online: https://digitalcommons.lmu. edu/cate/vol7/iss1/7 (accessed on 14 October 2021).

29. Dziewonski, K.; Korcelli, P. Migration and Settlement: 11. Poland; IIASA Research Report; IIASA: Laxenburg, Austria, 1981.

30. Jałowiecki, B. The main features of urbanization processes in Poland. Pol. Round Table 1980, 100, 73-97.

31. Pietraszek, E. Uwagi o aspektach i wskaźnikach urbanizacji wsi. In Procesy Urbanizacji Kraju w Okresie XXX-Lecia Polskiej Rzeczypospolitej Ludowej; Turowski, J., Ed.; Zakład Narodowy Ossolińskich: Wrocław, Poland, 1978.

32. Lane, D. Structural and social change in Poland. In Social Groups in Polish Society; Lane, D., Kolankiewicz, G., Eds.; Springer: Berlin/Heidelberg, Germany; Palgrave: London, UK, 1973; pp. 211-248.

33. Ziemer, K. Review of Sisyphus: Sociological studies. Vol. III, Crises and conflicts: The case of Poland 1980-81 Polish Academy of Sciences, Institute of Philosophy and Sociology. Eur. Sociol. Rev. 1985, 1, 255-257. [CrossRef]

34. Medvedkov, O. Soviet Urbanization; Routledge: New York, NY, USA, 1990.

35. Markowski, T. Ekonomiczny wymiar urbanizacji. In Przestrzeń Życia Polaków; Sepioł, J., Ed.; Stowarzyszenie Architektów Polskich SARP: Warsaw, Poland, 2015.

36. Szewrański, S.; Kazak, J.; Żmuda, R.; Wawer, R. Indicator-based assessment for soil resource management in the Wrocław larger urban zone of Poland. Pol. J. Environ. Stud. 2017, 26, 2239-2248. [CrossRef]

37. Dawid, W. Potencjalne koszty suburbanizacji. Zarys problematyki oraz praktyka badawcza. Urban Dev. Issues 2020, 66, 35-43. [CrossRef]

38. Śleszyńnski, P.; Kowalewski, A.; Markowski, T.; Legutko-Kobus, P.; Nowak, M. The contemporary economic costs of spatial chaos: Evidence from Poland. Land 2020, 9, 214. [CrossRef]

39. Lityński, P.; Hołuj, A. Urban sprawl costs: The valuation of households' losses in Poland. J. Settl. Spat. Plan. 2017, 8, 11-35. [CrossRef]

40. Szmytkie, R. Suburbanisation processes within and outside the city: The development of intra-urban suburbs in Wrocław, Poland. Morav. Geogr. Rep. 2021, 29, 149-165. [CrossRef]

41. Kurek, S.; Rachwał, T.; Wójtowicz, M. Industrial and commercial suburbanization in post-socialist city: The Kraków Metropolitan Area (Poland). Ann. Univ. Paedagog. Crac. Stud. Geogr. 2014, 5, 55-76.

42. Mantey, D.; Sudra, P. Types of suburbs in post-socialist Poland and their potential for creating public spaces. Cities 2019, 88, 209-221. [CrossRef]

43. Jadach-Sepioło, A.; Zathey, M. Alternative between revitalisation of city centres and the rising costs of extensive land use from a Polish perspective. Land 2021, 10, 488. [CrossRef] 
44. Dmochowska-Dudek, K.; Bednarek-Szczepańska, M. A profile of the Polish rural NIMBYist. J. Rural Stud. 2018, 58, 52-66. [CrossRef]

45. Ravenstein, E.G. The Laws of Migration. J. R. Stat. Soc. 1889, 52, 241-305. [CrossRef]

46. Lee, E. Applied political theory and qualitative research in migration studies. Demography 1966, 3, 47-57. [CrossRef]

47. Harris, J.R.; Todaro, M.P. Migration, unemployment and developmnent: A two-sector analysis. Am. Econ. Rev. 1970, 60, 126-142.

48. Todaro, M. Internal migration in developing countries: A survey. In Population and Economic Change in Developing Countries; Easterlin, R., Ed.; University of Chicago Press: Chicago, IL, USA, 1980; Volume 1, pp. 361-402. ISBN 0-226-18027-1.

49. Sjaastad, L.A. The costs and returns of human migration. J. Polit. Econ. 1962, 70, 80-93. [CrossRef]

50. Jończy, R. Bezrobocie jako zjawisko ekonomiczne. In Elementy Makroekonomii; Becka, A., Czaja, S., Grabowska, M., Jakubowski, R., Jończy, R., Eds.; I-BIS: Wrocław, Poland, 2002.

51. Barcus, H.R. Urban-rural migration in the USA: An analysis of residential satisfaction. Reg. Stud. 2004, 38, 643-657. [CrossRef]

52. De Jong, G.F.; Root, B.D.; Gardner, R.W.; Fawcett, J.T.; Abad, R.G. Migration intentions and behavior: Decision making in a rural Philippine province. Popul. Environ. 1985, 8, 41-62. [CrossRef]

53. Sasser, A.C. Voting with their feet: Relative economic conditions and state migration patterns. Reg. Sci. Urban Econ. 2010, 40, 122-135. [CrossRef]

54. Stawarz, N.; Sander, N.; Sulak, H. Internal migration and housing costs-A panel analysis for Germany. Popul. Space Place 2021, 27, 1-12. [CrossRef]

55. Borjas, G.J.; Bronars, S.G.; Trejo, S.J. Self-selection and internal migration in the United States. J. Urban Econ. 1992, 32, 159-185. [CrossRef]

56. Okólski, M. Costs and Benefits of Migration for Central European Countries; Centre of Migration Research (CMR), University of Warsaw: Warsaw, Poland, 2006.

57. Fuguitt, G.V.; Brown, D.L. Residential preferences and population redistribution: 1972-1988. Demography 1990, 27, 589-600. [CrossRef]

58. Smutek, J. Migracje ludności na tereny podmiejskie a rozwój usług w obszarach metropolitalnych w Polsce w latach 2000-2010. Ekon. Probl. Ustug. 2012, 95, 203-216.

59. Rosner, A. Współczesne procesy zmian zaludnienia obszarów wiejskich w Polsce. Stud. KPZK 2016, 167, $232-248$.

60. Frey, W.H.; Liaw, K.L.; Lian, G. State magnets for different elderly migrant types in the United States. Int. J. Popul. Geogr. 2000, 44, 21-44. [CrossRef]

61. Zaiceva, A. The impact of aging on the scale of migration. IZA World Labor 2014, 99, 15185. [CrossRef]

62. Germani, A.R.; Scaramozzino, P.; Castaldo, A.; Talamo, G. Does air pollution influence internal migration? An empirical investigation on Italian provinces. Environ. Sci. Policy 2021, 120, 11-20. [CrossRef]

63. Von Weizsaecker, E.U.; Lovins, A.; Lovins, L. Faktor Vier. Doppelter Wohlstand-Halbierter Naturverbrauch; Knaur: Munich, Germany, 1997.

64. Ben Yishay, A.; Fraker, A.; Guiteras, R.; Palloni, G.; Shah, N.B.; Shirrell, S.; Wang, P. Microcredit and willingness to pay for environmental quality: Evidence from a randomized-controlled trial of finance for sanitation in rural Cambodia. J. Environ. Econ. Manag. 2017, 86, 121-140. [CrossRef]

65. Eimermann, M.; Lundmark, M.; Müller, D.K. Exploring dutch migration to rural sweden: International counterurbanisation in the eu. Tijdschr. Voor Econ. En. Soc. Geogr. 2012, 103, 330-346. [CrossRef]

66. Scott, M.; Murphy, E.; Gkartzios, M. Placing 'Home' and 'Family' in Rural Residential Mobilities. Sociol. Rural. 2017, 57, 598-621. [CrossRef]

67. OECD. Rethinking Urban Sprawl: Moving towards Sustainable Cities; OECD Publishing: Paris, France, 2018.

68. Bourne, L.S. Reinventing the suburbs: Old myths and new realities. Prog. Plann. 1996, 46, 163-184. [CrossRef]

69. Matarrita-Cascante, D. Moving the amenity migration literature forward: Understanding community-level factors associated with positive outcomes after amenity-driven change. J. Rural Stud. 2017, 53, 26-34. [CrossRef]

70. Christiansen, P.; Loftsgarden, T. Drivers behind Urban Sprawl in Europe; TØI Report 1136/2011; Institute of Transport Economics (TØI): Oslo, Norway, 2011.

71. Lorens, P. Trends and problems of contemporary urbanization processes in Poland. In Spatial Planning and Urban Development in the New EU Member States; Altrock, U., Güntner, S., Peters, D., Eds.; Routledge: London, UK, 2006.

72. Bartoš, M.; Kušová, D.; Tesitel, J.; Kopp, J.; Novotná, M. Amenity migration in the context of landscape-ecology research. J. Landsc. Ecol. 2008, 1, 5-21. [CrossRef]

73. Milanović, N.; Gutry-Korycka, M.; Rink, D. Sprawl in the post socialist city: The changing economic and institutional context of central and eastern European cities. In Urban Sprawl in Europe: Landscapes, Land-Use Change E Policy; Couch, C., Leontidou, L., Petschel-Held, G., Eds.; Real Estate Issues; Blackwell: Oxford, UK, 2007; pp. 102-135.

74. Gosnell, H.; Abrams, J. Amenity migration: Diverse conceptualizations of drivers, socioeconomic dimensions, and emerging challenges. GeoJournal 2011, 76, 303-322. [CrossRef]

75. Bērziňš, M.; Krišjāne, Z. Amenity migration in postsocialist metropolis: The case Of Riga agglomeration. Proc. Latv. Acad. Sci. Sect. B Nat. Exact Appl. Sci. 2008, 62, 71-77. [CrossRef]

76. Bartoš, M.; Kušová, D.; Těšitel, J. Motivation and life style of the Czech amenity migrants (case study). Eur. Ctry. 2009, 1, 164-179. [CrossRef] 
77. Glorioso, R.S.; Moss, L.A.G. Amenity migration to mountain regions: Current knowledge and a strategic construct for sustainable management. Soc. Chang. 2007, 37, 137-161. [CrossRef]

78. Kłos, L. Równowaga życiowa jako uwarunkowanie ekomigracji. Eduk. Humanist. 2019, 2, 27-38.

79. Johnson, K.M.; Stewart, S.I. Recreation, amenity migration and urban proximity. In Amenities and Rural Development: Theory, Methods and Public Policy; Green, G.P., Deller, S.C., Marcouille, D.D., Eds.; Edward Elgar Publishing: Cheltenham, UK, 2005; pp. 177-196. ISBN 9781845428075.

80. Qvistrom, M.; Bengtsson, J.; Vicenzotti, V. Part-time amenity migrants: Revealing the importance of second homes for senior residents in a transit-oriented development. Land Use Policy 2016, 56, 169-178. [CrossRef]

81. Novotná, M.; Preis, J.; Kopp, J.; Bartoš, M. Changes in migration to rural regions in the Czech Republic: Position and perspectives. Morav. Geogr. Rep. 2013, 21, 37-54. [CrossRef]

82. European Environment Agency. Urban Sprawl in Europe. The Ignored Challenge; EEA Report No.10/2006; European Environment Agency: Copenhagen, Denmark, 2006; ISBN 92-9167-887-2.

83. Stępień, J.; Michalski, T.; Grabowski, J.; Waszak, P.; Grabkowska, M.; Macul, A.; Rojek, J.J. Social response and spatial mobility change due to COVID-19 pandemic in Poland. Geogr. Pol. 2021, 94, 381-396. [CrossRef]

84. Struzik, J. Analiza prasy. In O Wsi Bez Uprzedzeń; Raport z Badań; Struzik, J., Ed.; Fundacja Przestrzeń Kobiet: Kraków, Poland, 2019; ISBN 9788393713073.

85. Gonda-Soroczyńska, E. Przemiany strefy podmiejskiej Wrocławia w ostatnim dziesiesięcioleciu. Infrastrukt. Ekol. Teren. Wiej. 2009, 04, 149-165.

86. Šimon, M. Exploring Counterurbanisation in a Post-Socialist Context: Case of the Czech Republic. Sociol. Rural. 2014, 54, 117-142. [CrossRef]

87. Kondo, M.C.; Rivera, R.F.; Rullman, S.D. Protecting the idyll but not the environment: Second homes, amenity migration and rural exclusion in Washington State. Landsc. Urban Plan. 2012, 106, 174-182. [CrossRef]

88. Rudzitis, G. Amenities Increasingly Draw People to the Rural West. Rural Dev. Perspect. 1999, 14. [CrossRef]

89. Hansen, A.J.; Rasker, R.; Maxwell, B.; Rotella, J.J.; Johnson, J.D.; Parmenter, A.W.; Langner, U.; Cohen, W.B.; Lawrence, R.L.; Kraska, M.P. V Ecological Causes and Consequences of Demographic Change in the New West: As natural amenities attract people and commerce to the rural west, the resulting land-use changes threaten biodiversity, even in protected areas, and challenge efforts to sustain local communities and ecosystem. Bioscience 2002, 52, 151-162. [CrossRef]

90. Jimenez, Y.G.; Aráoz, E.; Fernandez, R.D.; Nanni, S.; Ovejero, R.; Paolini, L.; Grau, H.R. Counterurbanization: A neglected pathway of forest transition. Ambio 2021. [CrossRef] [PubMed]

91. Ołów-Wachowicz, A. Zmęczeni miastem. Nowi mieszkańcy, nowy styl życia. Kierun. Zmian 2020, 3, 17-20.

92. Wrona, A. Przeprowadzki z miast do wsi-spotkanie dwóch kultur i co z niego wynika dla lokalnych społeczności. Górnoślaskie Stud. Socjol. 2015, 6, 123-144.

93. Bende, C.; Nagy, G. Community gardens in post-socialist Hungary: Differences and similarities. Geogr. Pol. 2020, 93, 211-228. [CrossRef]

94. Millennium Ecosystem Assessment. Ecosystems and Human Well-Being: Synthesis; Island Press: Washington, DC, USA, 2005.

95. Halliday, J.; Coombes, M. In search of counterurbanisation: Some evidence from Devon on the relationship between patterns of migration and motivation. J. Rural Stud. 1995, 11, 433-446. [CrossRef]

96. Kłos, L. Uwarunkowania ekomigracji w Polsce. Optimum. Stud. Ekon. 2017, 1, 130-142. [CrossRef]

97. Bender, O.; Kanitscheider, S. Amenity migration in the Southern Andes and the Southern European Alps-A key factor for sustainable regional development? Mitt. Der Osterr. Geogr. Ges. 2013, 155, 105-124. [CrossRef]

98. Müller, D.K. Amenity migration and tourism development in the Tärna Mountains, Sweden. Amenity Migr. Seek. Sustain. Mt. Cult. 2006, 245-258. [CrossRef]

99. Píša, J. The lawn grew too quickly! Perception of rural idyll by Czech amenity migrants. GeoScape 2019, 13, 55-67. [CrossRef]

100. Sylla, M.; Lasota, T.; Szewrański, S. Valuing environmental amenities in peri-urban areas: Evidence from Poland. Sustainability 2019, 11, 570. [CrossRef]

101. Cooke, B.; Lane, R. How do amenity migrants learn to be environmental stewards of rural landscapes? Landsc. Urban Plan. 2015, 134, 43-52. [CrossRef]

102. Yuan, J.; Beard, K.; Johnson, T.R. A quantitative assessment of spatial patterns of socio-demographic change in coastal Maine: One process or many? Appl. Geogr. 2021, 134, 43-52. [CrossRef]

103. Píša, J.; Hruška, V. Entrepreneurial in-migration and rural development in Czechia: A challenge of integrating the local and extra-local in rural planning. Geogr. Pol. 2019, 92, 347-383. [CrossRef]

104. Jończy, R. Migracje Zagraniczne z Obszarów Wiejskich Województwa Opolskiego po Akcesji Polski do Unii Europejskiej. Wybrane Aspekty Demograficzne i Ekonomiczne; Instytut Ślaski: Wrocław, Poland, 2010.

105. Babbie, E. The Practice of Social Research; Wadsworth Publishing Company: Wadsworth, OH, USA, 2004; ISBN 83-01-14068-2.

106. Spreen, M. Rare populations, hidden populations, and link-tracing designs: What and why? Bull. Sociol. Methodol. 1992, 36, 34-58. [CrossRef]

107. Kirchherr, J.; Charles, K. Enhancing the sample diversity of snowball samples: Recommendations from a research project on anti-dam movements in Southeast Asia. PLoS ONE 2018, 13, e0201710. [CrossRef] 
108. Zysk, E. Funkcja mieszkaniowa na obszarach wiejskich na przykładzie gminy Stawiguda-Aspekty społeczne i rynku nieruchomości. In Planowanie Rozwoju Przestrzeni Wiejskiej; Kurowska, K., Ed.; Urząd Marszałkowski Województwa WarmińskoMazurskiego: Olsztyn, Poland, 2013.

109. Xu, Y.; Zhang, X. The residential resettlement in suburbs of Chinese cities: A case study of Changsha. Cities 2017, 69, 46-55. [CrossRef]

110. Biolek, J.; Andráško, I.; Malý, J.; Zrůstová, P. Interrelated aspects of residential suburbanization and collective quality of life: A case study in Czech suburbs. Acta Geogr. Slov. 2017, 57, 65-75. [CrossRef]

111. Hlaváček, P.; Kopáček, M.; Horáčková, L. Impact of suburbanisation on sustainable development of settlements in suburban spaces: Smart and new solutions. Sustainability 2019, 11, 7182. [CrossRef]

112. Mantey, D. Social consequences of gated communities: The case of suburban Warsaw. Prof. Geogr. 2017, 69, 151-161. [CrossRef]

113. Kajdanek, K. Suburbanizacja po Polsku; Zakład Wydawniczy Nomos: Kraków, Poland, 2012.

114. Bogusz, H.; Wójcik, P.; Winnicki, S. What Factors Determine Unequal Suburbanisation? New Evidence from Warsaw, Poland; University of Warsaw: Warsaw, Poland, 2020.

115. Tiebout, C.M. A pure theory of local expenditures. J. Polit. Econ. 1956, 64, 416-424. [CrossRef]

116. Jargowsky, P.A.; Park, Y. Cause or Consequence?: Suburbanization and crime in U.S. Metropolitan Areas. Crime Delinq. 2009, 55, 28-50. [CrossRef]

117. Kajdanek, K. Pomiędzy Miastem a Wsia. Suburbanizacja na Przykładzie Osiedli Podmiejskich Wrocławia; Nomos: Kraków, Poland, 2011; ISBN 978-83-7688-243-7.

118. Lee, B.A.; Oropesa, R.S.; Kanan, J.W. Neighborhood Context and Residential Mobility. Demography 1994, 31, 249-270. [CrossRef]

119. Marshall, H.H.; Stahura, J.M.; Marshall, H.H. Determinants of black suburbanization: Regional and suburban size category patterns. Sociol. Quaterly 2016, 20, 237-253. [CrossRef]

120. Gebre, T.; Gebremedhin, B. The mutual benefits of promoting rural-urban interdependence through linked ecosystem services. Glob. Ecol. Conserv. 2019, 20, e00707. [CrossRef]

121. Kurre, J.A. Is the cost of living less In rural areas? Int. Reg. Sci. Rev. 2003, 26, 86-116. [CrossRef]

122. Komorowski, Ł.; Stanny, M. Smart villages: Where can they happen? Land 2020, 9, 151. [CrossRef]

123. Pandas, A. Suburbanisation as a factor in increasing life expectancy. Ekonomia 2020, 26, 65-74. [CrossRef]

124. Kristóf, A. The impact of suburbanization on social differentiation in Hungary: A case study of the Miskolc agglomeration. Geogr. Pannonica 2018, 22, 176-188. [CrossRef]

125. Morris, E.A. Do cities or suburbs offer higher quality of life? Intrametropolitan location, activity patterns, access, and subjective well-being. Cities 2019, 89, 228-242. [CrossRef]

126. Bereitschaft, B. Adult population and neighborhood walkability by metropolitan area size and degree of urban sprawl. Pap. Appl. Geogr. 2021, 1-21. [CrossRef]

127. Willing, R.; Pojani, D. Is the suburban dream still alive in Australia? Evidence from Brisbane. Aust. Plan. 2017, 54, 67-79. [CrossRef]

128. Špačková, P.; Dvořáková, N.; Tobrmanová, M. Residential Satisfaction and Intention to Move: The case of Prague's New Suburbanites. Geogr. Ann. Ser. B Hum. Geogr. 2016, 98, 331-348.

129. Źróbek-Różańska, A.; Zadworny, D. Can urban sprawl lead to urban people governing rural areas? Evidence from the Dywity Commune, Poland. Cities 2016, 59, 57-65. [CrossRef]

130. Kruszyna, M.; Śleszyński, P.; Rychlewski, J. Dependencies between demographic urbanization and the agglomeration road traffic volumes: Evidence from Poland. Land 2021, 10, 47. [CrossRef]

131. Woźniak, M. Zrównoważona gospodarka energetyczna na obszarach wiejskich w Polsce. Polityka Energ. 2018, $21,69-84$.

132. Hanušin, J. Impact of dispersed settlement on the structure and diversity of rural landscape (Case study of village Hrušov, Slovak Republic). Geogr. Pol. 2021, 94, 29-46. [CrossRef]

133. Oleniacz, R.; Gorzelnik, T.; Bogacki, M. Impact of urban, suburban and industrial background on air pollution levels of dust substances in North-Eastern part of Krakow (Poland). IOP Conf. Ser. Earth Environ. Sci. 2021, 642, 012013. [CrossRef]

134. Legutko-Kobus, P.; Nowak, M.J. Inefficiency of public authorities in the light of legal, spatial, and participatory urban regeneration tools. Public Policy Stud. 2020, 7, 117-135. [CrossRef]

135. Nadin, V.; Fernández Maldonado, A.M.; Zonneveld, W.; Stead, D.; Dabrowski, M.; Piskorek, K.; Sarkar, A.; Schmitt, P.; Smas, L.; Cotella, G.; et al. Comparative Analysis of Territorial Governance and Spatial Planning Systems in Europe; ESPON EGTC: Luxembourg, 2018; ISBN 978-99959-55-55-7.

136. Źróbek-Różańska, A.; Wolny, A. Zatrzymać czy pozwolić? Nieoczywiste skutki suburbanizacji. Studium podolsztyńskich gmin wiejskich. Stud. Miej. 2017, 26, 9-23. [CrossRef] 